

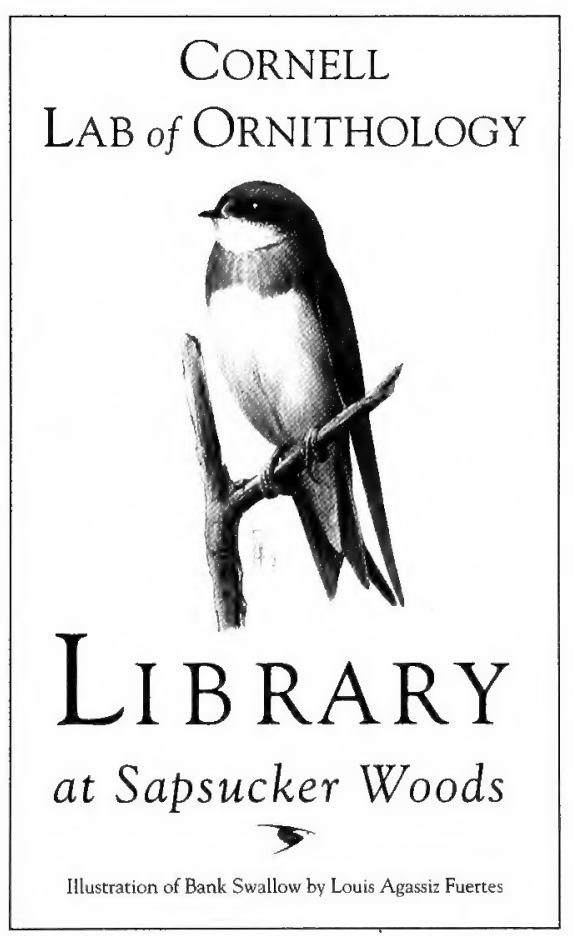


QL 676 Cornell University Library

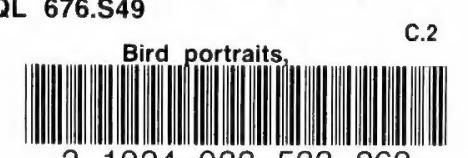

$\begin{array}{lllll}3 & 1924 & 022 & 533 & 263\end{array}$ 


\section{Cornell University Library}

The original of this book is in the Cornell University Library.

There are no known copyright restrictions in the United States on the use of the text. 


\section{BIRD PORTRAITS}






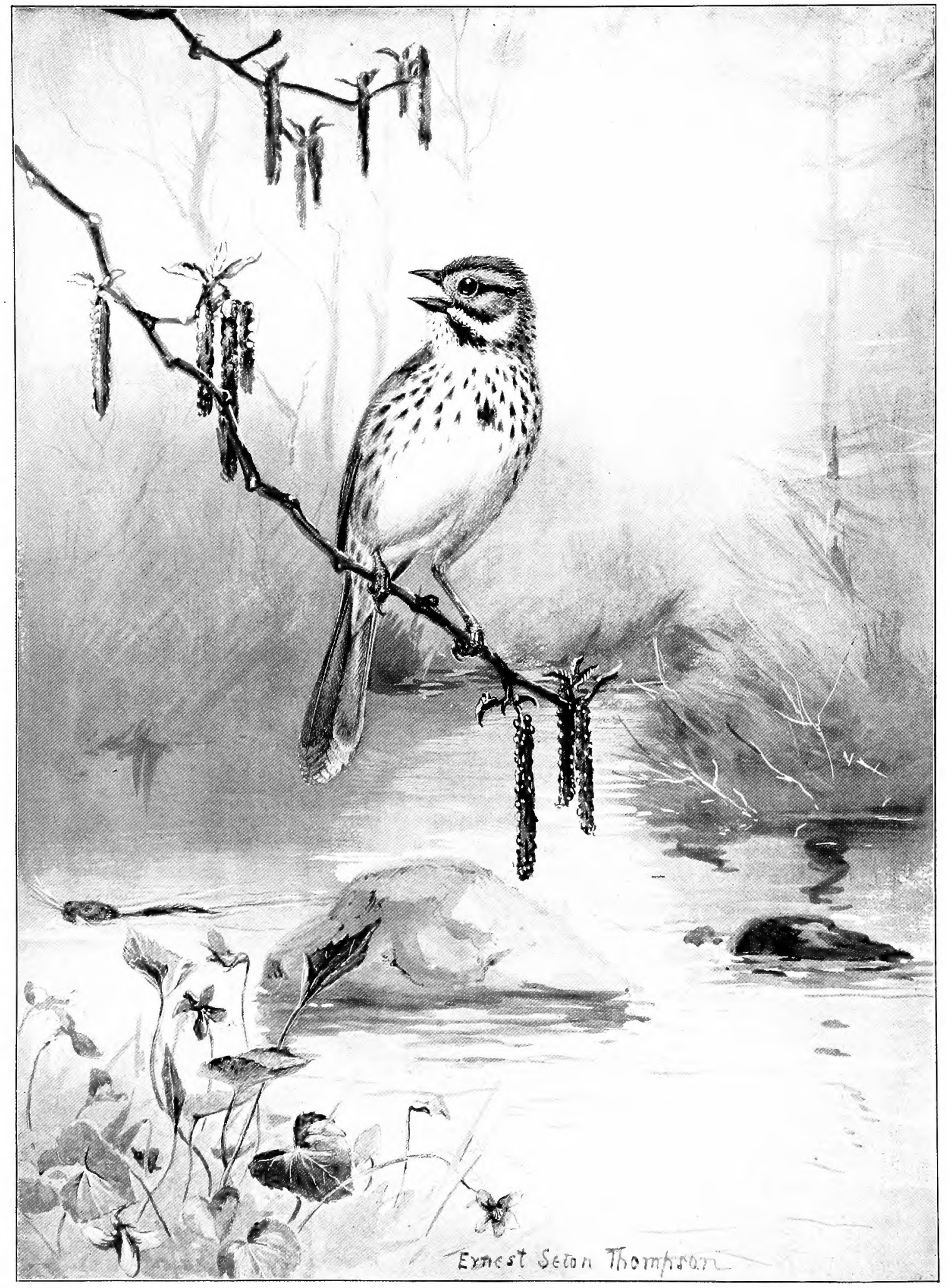

THE SONG SPARROW 


\title{
BIRD PORTRAITS
}

\section{By Ernest Seton-Thompson}

\author{
WITH DESCRIPTIVE TEXT \\ By Ralph Hoffmann
}

Ginn $\stackrel{\text { BOSton }}{\& \text { Company }}$

The Athenxum 犯regi

1901

D. \& 6 


$$
\begin{aligned}
& \text { Ornith. } \\
& \text { QL } \\
& 676 \\
& 549
\end{aligned}
$$

389912

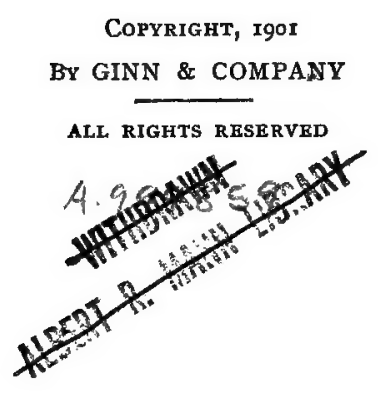




\section{CONTENTS}

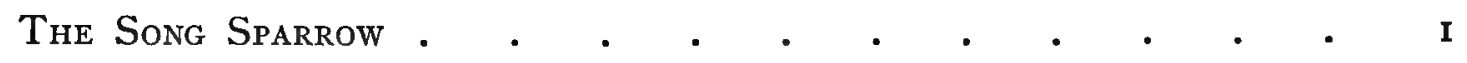

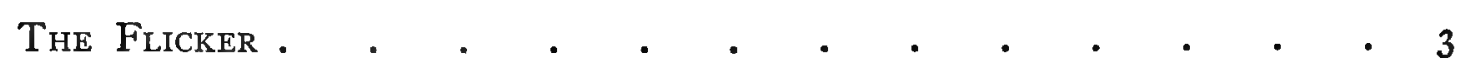

The Brown Thrasher.$\quad \cdot \quad \cdot \quad \cdot \quad \cdot \quad \cdot \quad \cdot \quad \cdot \quad \cdot \quad 5$

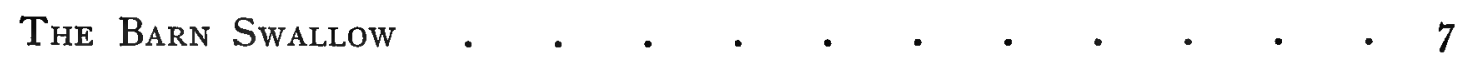

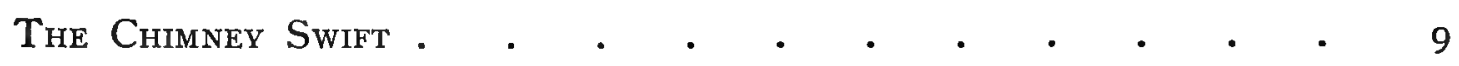

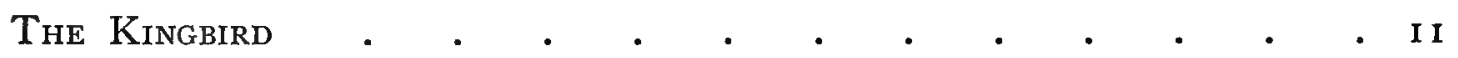

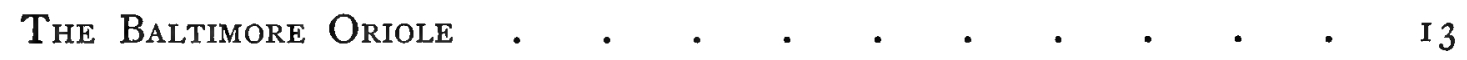

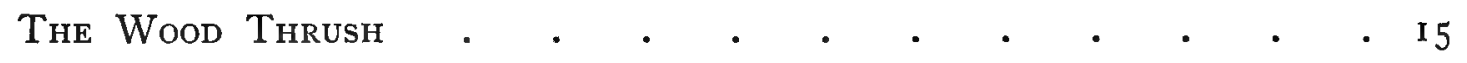

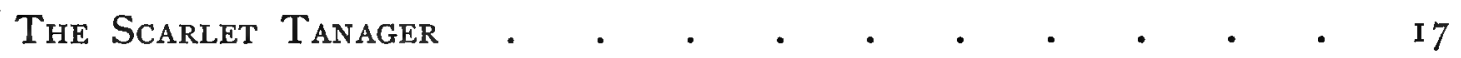

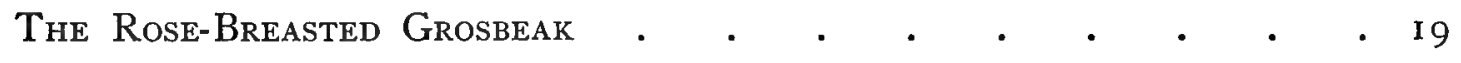

The Redstart . . . . . . . . . . . . . . . $2 \mathrm{I}$

The Ruby-Throated Humming-Bird . . . . . . . . . 23

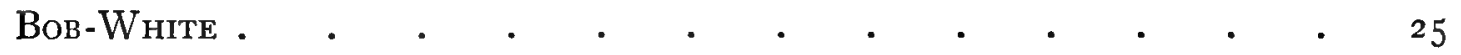

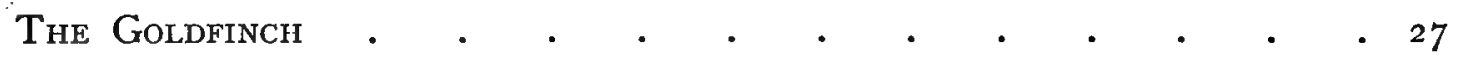

The Blue Jay

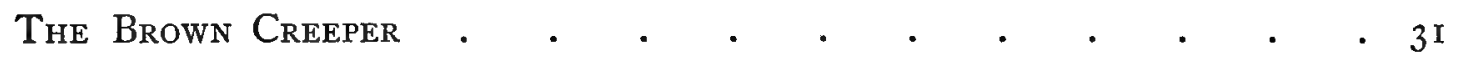

The Butcher Bird • . . . . . . . . . . . . . 33

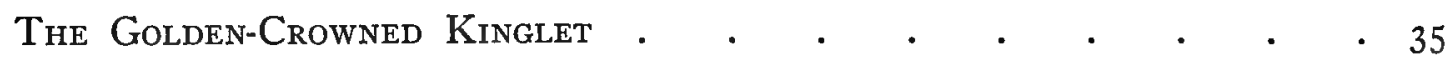

The Herring Gull . . . . . . . . . . . . . 37

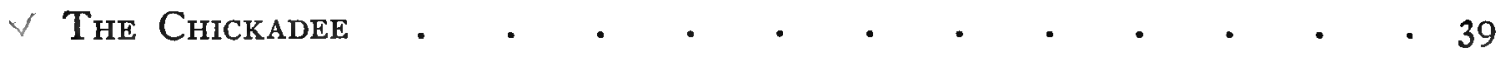





\section{INTRODUCTION}

This book is called "Bird Portraits" because Mr. Seton-Thompson's pictures are always faithful and charming portraits of the birds which he drawes. But since a bird's portrait, no matter how accurate, can show its subject in only one position, singing, feeding, flying, or sitting, a short account of some of the main events of the bird's life has been added to each picture.

Any one who learns from such books as Mr. Seton-Thompson's how beset with perils is the life of every wild creature will take the greatest pains at all times, and especially in the nesting season, not only not to injure or persecute such defenseless little creatures as our song birds, but also to protect them in every way. Whoever seeks their acquaintance, in the spirit of friendship, will always be grateful for the interest and pleasure to be gained from such friends.

Of the twenty birds whose portraits are here presented, a majority are only summer residents in the Northern States; some visit us only in winter; a few spend the whole year near the same spot. The birds which are first described are those that are most closely associated with the return of spring; then follow those whose gay colors and bright songs give much of its charm to early summer; last come those that brave, even in the North, the tempests of winter.

R. H. 



\section{BIRD PORTRAITS}

\section{THE SONG SPARROW}

After a severe winter, while snow and ice still remind us of the past, the Song Sparrow, mounting to the top of some bush or small tree, repeats his cheerful tinkling song, "helping," as Thoreau says, "to crack the ice" in the ponds. Few people are so unobservant as not to notice this bright strain, after the silence of winter. A peculiarity of the song is the amount of variation shown by different individuals and often by the same bird. At almost regular distances along the bushy roadside, or over the hedge-intersected fields, one will meet on the early spring mornings one Song Sparrow after another, each restricted to his part of the road or field. If one notices the songs of each, it is evident that, though the songs have the same general character, there are almost as many ways of beginning a strain as there are singers. Moreover, the same bird has been observed to alter his song in a short space of time to two or three different variations. Probably, if one's ear were acute enough, all birds of one species would be found to sing with slight differences, but few show in so marked a degree as the Song Sparrow the tendency to variation which characterizes a species.

In early April, the Song Sparrow builds a nest of grass, either on the ground beneath a tuft of grass, or under some brambles, or less frequently a few feet above the ground, in a bush or on the lower limbs of a tree. In the latter situation, twigs are of course necessary for the support of the structure. Here again the bird shows a tendency to vary in its habits. The eggs are from four 
to five in number, greenish white, thickly marked with shades of brown, lavender, or purple. Sometimes an egg is found in the nest much larger than the others; this has been laid by the lazy Cowbird. As the large egg receives most warmth and hatches first, the young Cowbird soon crowds out the rightful occupants of the nest, and the parent Song Sparrows will be seen later, working busily to feed a great homely youngster as large as themselves, who will afterwards go off to join a flock of his own kind. Probably every Cowbird has been reared at the expense of a brood of some small bird, Sparrow, Warbler, or Vireo.

In June, the young Song Sparrows are able to take care of themselves, and the energetic parents build another nest and rear another brood. The brooding time is the chief period of song, so that birds that breed twice sing later in the summer than others. The Song Sparrow's little strain may be heard well into August; but toward the end of that month we hear from the cornfields and gardens a curious, husky warble, unlike the bright spring carol of the Song Sparrow, but nevertheless made by that bird. In the fall, and even during the winter, a warm bright day will occasionally induce a Song Sparrow to sing his lively spring song, so that where the Song Sparrow winters, the strain may be heard every month of the year.

In the late summer and fall, the neglected corners of gardens and fields, where the seeds of weeds and grasses offer an abundance of food, are the favorite resort of the sparrows. The Song Sparrow may be distinguished from most of its relatives by its streaked breast, in the middle of which the spots generally form a conspicuous blotch, and by its long tail, which it constantly jerks as it flies. The Song Sparrow is very retiring, and when alarmed, slips into brush heaps or bushes, where it hides as skillfully as a mouse. 



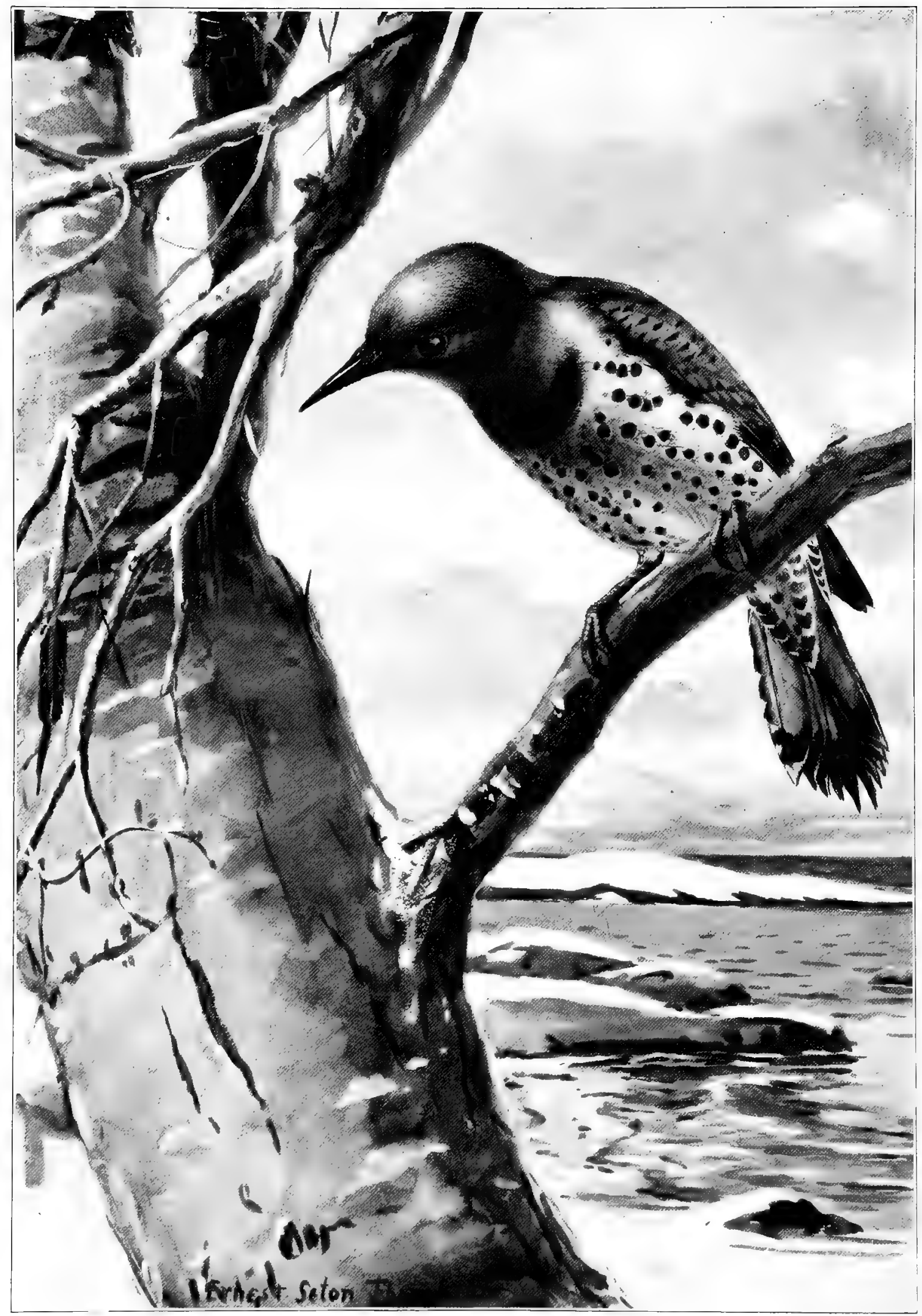




\section{THE FLICKER}

THE Flicker is most beloved in March, when his hearty shout is one of the characteristic sounds of the first warm days of early spring. The same week which brings the Bluebird and the Blackbird hears the cheerful song of the Song Sparrow and the loud call of the Flicker.

Though a woodpecker, the Flicker has departed somewhat from the habits of its relatives, spending considerable time on the ground, and depending largely for its food on berries and ants. It is often startled from lawns and hillsides, where it has been thrusting its long tongue into colonies of black ants, seizing them on the moist, brushy tip. When so engaged, the bird may sometimes be closely approached, and a sight of its plumage is then a revelation to one who has seen from a distance only its dark brown body and white rump. The ashy gray nape sets off a bright red patch; there is a handsome black crescent across the breast, and the male wears black mustaches. The breast is handsomely spotted, and the quills and undersides of the wing and tail feathers are golden yellow. Unless one can steal up close to a bird, few of these marks show; but the Flicker may always be distinguished by his size (he is the largest of our common birds except the Crow), by the white rump, and the gleam of yellow which has given him the name Golden-winged Woodpecker. The flight, too, like that of all the woodpeckers, is characteristic; the wing strokes are slow, and between them the bird drops a little, so that its progress is in waves instead of in a straight line. 
All the woodpeckers nest in holes, which they chisel out of decayed or even live wood. A circular entrance leads to a vertical passage, and this to a wide chamber some distance below. No lining of moss or feathers is put in; the pure white, nearly round eggs are laid directly on the chips at the bottom of the cavity, and the young birds after a few days hang by their claws to the side of the hole. Young Flickers, like young Humming-birds, are fed by their parents with a liquid food, which is pumped into their wideopened mouths, the parent's bill being thrust far into the young one's.

The Flicker is one of the few birds that frequently return to the old nest. Most birds, contrary to the common notion, instead of refurnishing the weather-beaten and insecure structure into which their last year's home has been converted by snow, rain, and wind, prefer to build a new one. The material is everywhere at hand, and time is not so precious before the young are hatched. The Flicker, however, having built in a stout limb, can safely return for several seasons to the same cavity, or, if this becomes insecure, can cut another in the same trunk. Branches are often seen where three or four round openings show the tenements of several generations of these noisy birds. South of Massachusetts, Flickers generally spend the whole year in one spot, and in winter live largely on berries; a favorite food at this season is the berry of the poison ivy. In the fall, the rum cherry becomes a resort for all fruit-loving species.

The Flicker, though not known to raise a second brood, has a second period of song, so that we hear again in June the shout, or mating call, of the early spring days. Besides this high-pitched wick, wick, wick, the Flicker utters, when startled, a curious note like worroo; a sharp ti'ou is the call to its kind, and the syllables yucker, yucker, often accompanied by ludicrous bowing with wings and tail outspread, are used to show affection. 



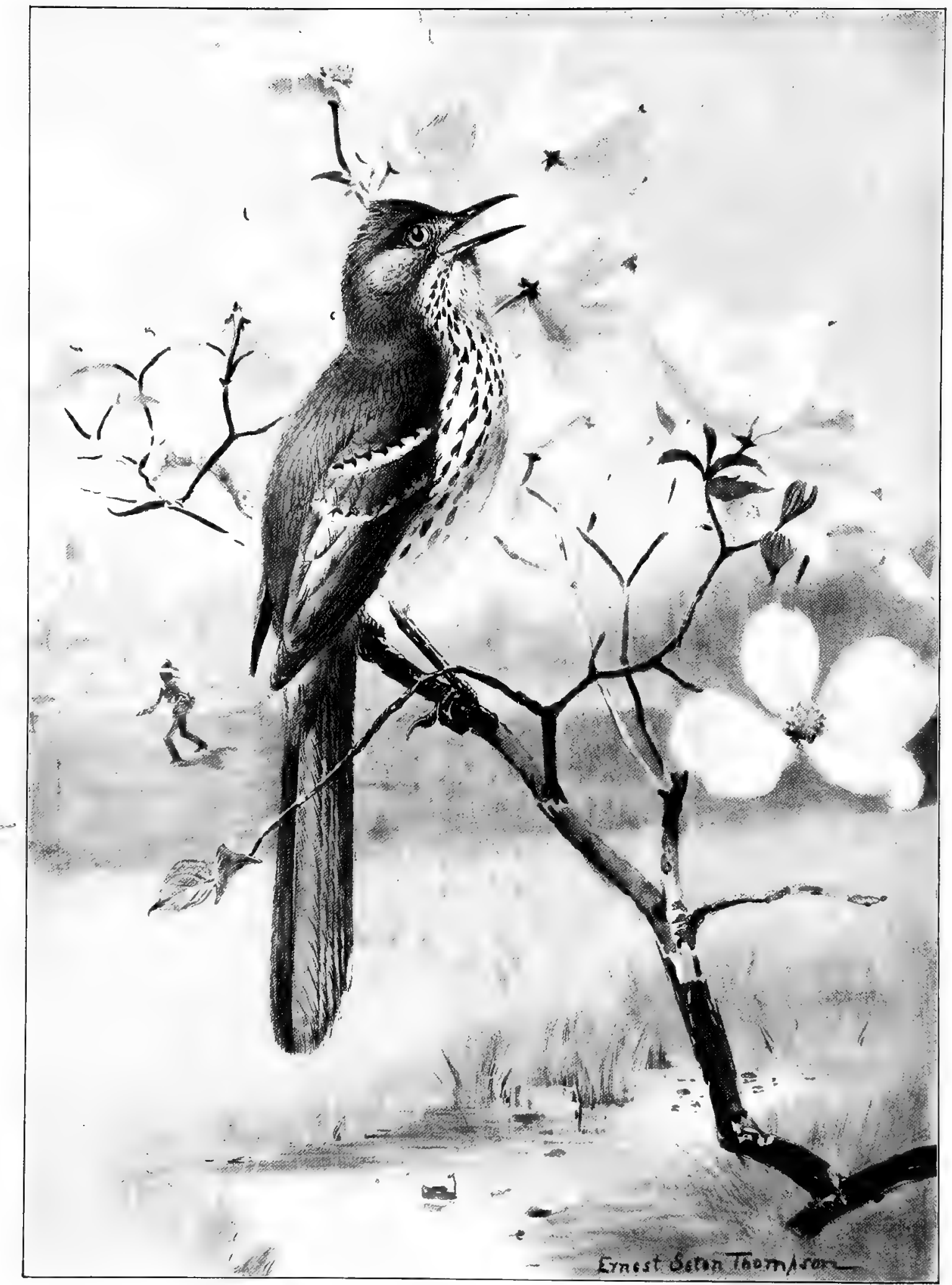

THE BROWN THRASHER 


\section{THE BROWN THRASHER}

ThE Thrasher is the first great musician of the year; he arrives in the last week of April, so that his song forms the prelude of the chorus which is given in May by the true Thrushes, the Bobolink, and the Oriole. There is a spirit, a brilliancy of execution, and a power in his song which is perhaps more appropriate to early spring than the rich, sweet tone of the birds who take up the strain in warmer days. He sings when spring, though assured, is not every. where manifest, and the vigor of his ringing phrases serves to dispel any lingering doubt that the faint-hearted may yet entertain.

The trees are yet leafless, and the singer can be seen afar off on the very topmost twig of some hillside tree; his long tail is held straight below him, his head is up-lifted, and from his full throat comes phrase after phrase, a succession of the most varied and apparently extremely difficult notes, executed with an ease and full-hearted joy which, to the ears of many, place the Thrasher in the class with the true Thrushes. Like the song of all male birds, the performance is not only an offering or an invitation to the female, but also an answer to some rival whose fainter notes reach the ear from the neighboring grove.

This last week of April is often one of the most delightful seasons of the year, and particularly attractive to a beginner in bird study. There are only a few bushes in leaf, and those of a delicate green; the dried leaves under them are starred with white bloodroot; on the hillsides, the purple violet and yellow five-finger are wide open in the warm sun, and in the woods, the mayflower and 
the hepatica surprise the visitor in spots where the late snow still lingers. The birds are easy to find; there is no dense foliage to hide them, and the number of species is still so few that their songs and figures are not difficult to distinguish.

The Thrasher's song ceases as you approach him. He slips down like a wren to the undergrowth, where, if you listen, you hear him rustling and scratching in the dry leaves. If you sit down near'by, you will see him as he mounts again from one twig to the next. His white breast is heavily spotted with black, his head, back, and tail are of a bright rufous shade, and his yellow eye glitters like a snake's. When he is alarmed, he puffs like a turtle, or utters a note curiously like a loud smack. The whole air of the bird is one of vigor and intelligence. The sexes are alike in size and color. By watching patiently near the spot where the male sings, it is often possible to surprise the pair bringing bark and roots to the bush among whose roots or stems the nest is woven.

It is one of the most delightful experiences in the study of birds thus to watch a pair of birds building their nest, to note later the laying of each egg, to see the female brooding till the nestlings are hatched and finally leave the nest. One always heaves a sigh of relief at the last moment, for so many tragedies may put an end to the story. The female Thrasher is very bold when on the nest, and sits close till the visitor, if he approach quietly, is within a few feet of her. She gazes fixedly at him with her bright eye, but let him draw a step nearer and she slips off into the bushes. The eggs are four or five, whitish, covered with many light brown markings.

The food of the Thrasher consists of insects and fruit. Many linger in the North till the end of October, and spend the winter in the Southern States, where the ground is generally free from snow. 



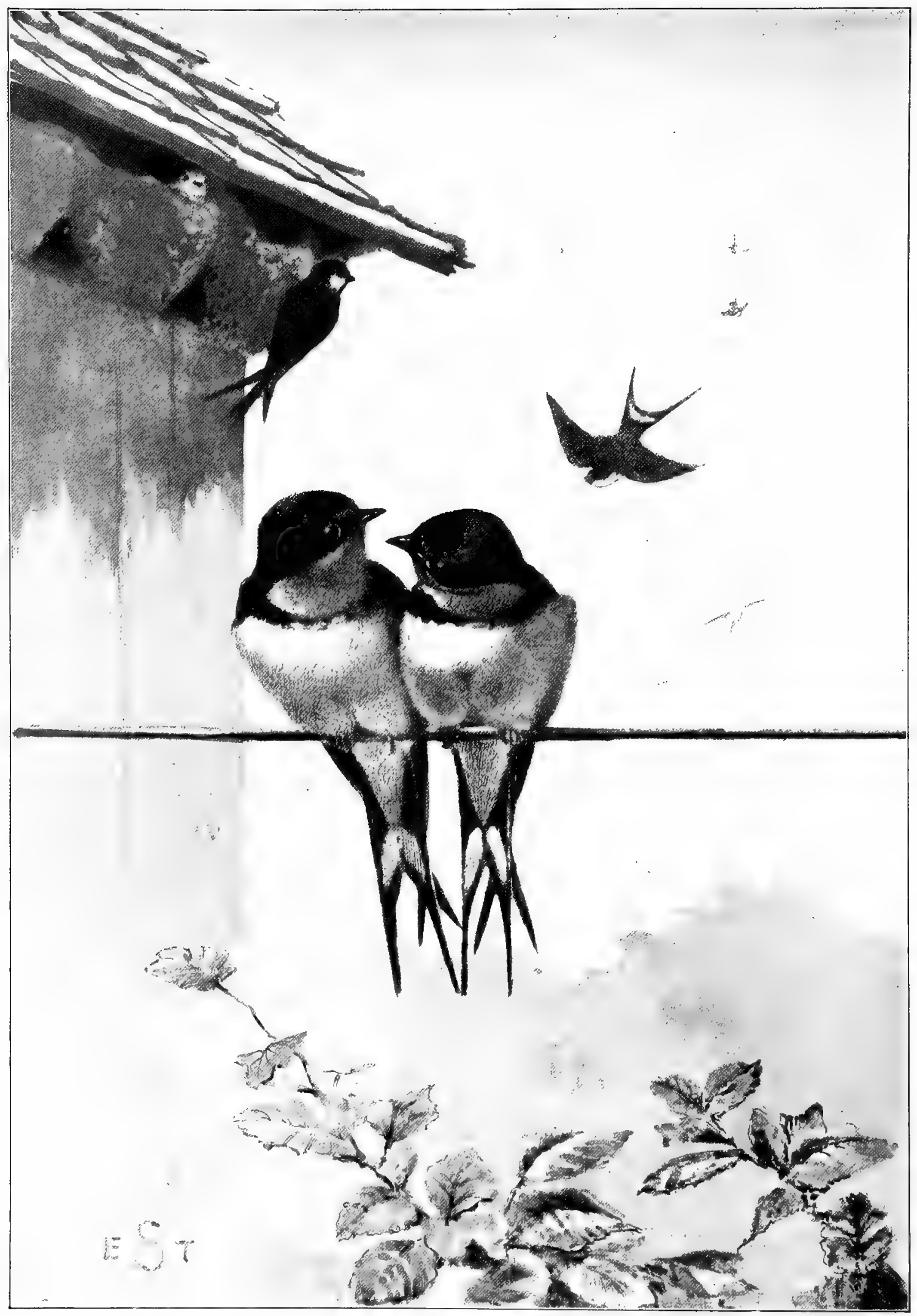

THE BARN SWALLOW 


\section{THE BARN SWALLOW}

THERE is no pleasanter sight among birds than a family of young reared in the neighborhood of man and often on some part of his house itself. Visit an old farmhouse; look about and see how many welcome guests the farmer shelters without thought of pecuniary profit. Under the woodshed, on a beam, the Phobe has built a nest of moss, from which she flies to the barnyard to pursue the insects that swarm there. In the vines on the piazza, Robins and Chipping Sparrows have reared their young. In the old elm over the door, an Oriole has woven a nest with thread twitched from the clothesline or perhaps purposely laid out for her, and the orchard shelters numbers of species - Bluebirds, Woodpeckers, Kingbirds, and Chebecs. Of all these tenants, however, none seem so completely at home as the swallows; none show so little concern at man's presence; none take possession so coolly of the boxes, the eaves, or the rafters where they build. Their kindred lived with man, ages ago, in Greece and Rome; they have been welcomed each spring as heralds of a joyful season; their departure has been watched with regret. Though they have but few notes which are musical, yet their grace, agility, and swiftness have passed into proverb and song.

There are several species of swallow, or martin, which take advantage of man's structures in or on which to place their nests, but the most numerous, the most familiar to people in general, and perhaps the most attractive, is the Barn Swallow. This is the only species whose outer tail feathers are long and pointed, and form 
with the rest of the tail the peculiar figure known as "swallow-tail." The head, back, wings, and tail are all of a beautiful lustrous blue, and the tail, when spread, shows large white spots in the inner feathers. The under parts vary from whitish in immature birds to a rich chestnut in fully mature ones, who have also the throat and forehead of a darker reddish brown. The bill opens far back, so that there is a wide cavity to engulf any insect which may be met in the ceaseless flight backward and forward over grass and water.

The nest of the Barn Swallow is familiar to all who have enjoyed life on a farm. It is made of straws and grass, plastered together with mud, and is placed on a beam or rafter in the barn. One hospitable farmer drove a horseshoe into a beam, and on this ledge a swallow built each year. Through the open door or window of the barn the swallows fly in and out, and up into the gloom above, where twittering sounds tell of young that are being fed. As soon as the young are old enough, the parents urge them to fly, and in a few days they become skillful enough to take food on the wing. This is an extremely pretty spectacle; the parent and the young meet, and then fly upward for an instant, their breasts apparently touching, while the food is passed from one bill to the other. One July afternoon the writer watched a row of six young swallows clinging to the shingles on a barn roof, every mouth gaping for food whenever the parents approached. When the father brought the food, the bird sitting nearest him got the mouthful, and in an instant later another from the mother. Five times in succession this favored youngster was fed, while the other five seemed neglected. But when the little fellow had all that he could hold, he went to sleep, and the next wide-open mouth received the food. What seemed at first an unfair arrangement was after all the surest way to feed all alike. 



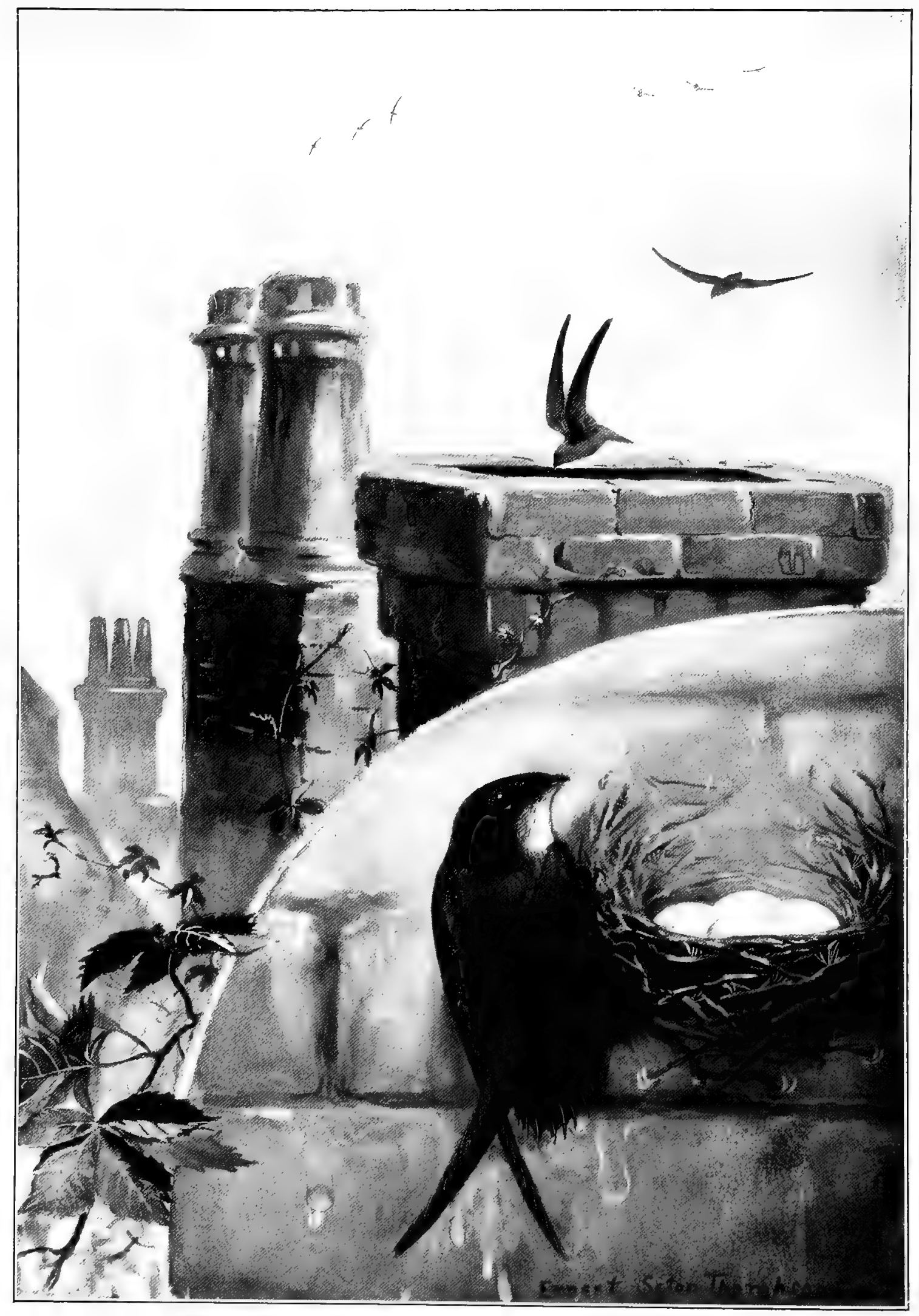

THE CHIMNEY SWIFT 


\section{THE CHIMNEY SWIFT}

The Swift is universally known as the Chimney Swallow, from a belief that it belongs to the swallow family. It is, in fact, no relative of the swallows, but very nearly related to the Whippoorwill and Night-hawk. Swifts and swallows both have long, powerful wings, which enable them to remain for long periods on the wing in a restless search for insects. Scientists themselves were for a long time misled by the resemblance in the appearance and habits of the two families, but a close examination of the skeleton of the two birds has convinced naturalists that the two families descended from different ancestors, but have arrived at similar solutions of the problem presented to them in their search for food.

The Swift builds, as is well known, in the flues of chimneys. It is often seen in May, dashing past the dead twigs of some tree, and then off to the chimney, where the twigs are glued together and to the bricks by the help of saliva secreted by the bird. A common and distressing experience after a storm in summer is the discovery of the young Chimney Swifts at the wrong end of the chimney, - on the hearth, in other words. Even in their proper place in the chimney, the young birds can make their presence very well known by beginning, as soon as it is light, an incessant clamor for food.

The long narrow wings, the powerful chest muscles, the cut of the bird's body, and the way the keel is ballasted, so to speak, enable the bird to remain for hours in constant flight without apparently experiencing the least fatigue. Swallows are often seen resting 
on telegraph wires, but I have never seen a Swift perch on any support outside a chimney. At night and during such part of the day as is given up to rest, the bird supports itself in chimneys by clinging to projections or crevices. The stiff, sharp-pointed tail feathers aid greatly in supporting it. Before the coming of the white man, hollow trees served as the roosting and nesting places of the Swifts.

There is no better practice for the eye than distinguishing swallows from Swifts, when both species are mingled in the air. The Swift's flight, though very powerful, suggests that of the bat, on account of the frequency of the wing strokes; the rapid beating of the wings ceases at intervals and the bird glides through the air or turns on set wings. Then the twinkling flight begins again. There are none of those long sweeping strokes with which the Barn Swallow cleaves the air. The tail of the Swift, when the bird is flying, generally appears short and cigar-shaped, or, if spread, it is fan-shaped, not forked like the tails of all the swallows.

The ordinary note of the Swift is a single sharp cry, slowly or rapidly repeated; it is characteristic of warm summer evenings when the birds fly about the houses in twos or threes, pursuing each other and uttering this note staccato. A pretty sight at this time is the Swift sailing with wings raised above the body, in the position of our common pigeon just before alighting; the Swift assumes the same attitude above the chimney, poising a moment before he drops into the flue.

Early in September the Swifts leave the North, and may be seen high overhead flying southward; unlike many of our small birds, they migrate by day, their powers of flight protecting them from the birds of prey which are such a menace to the smaller birds. 



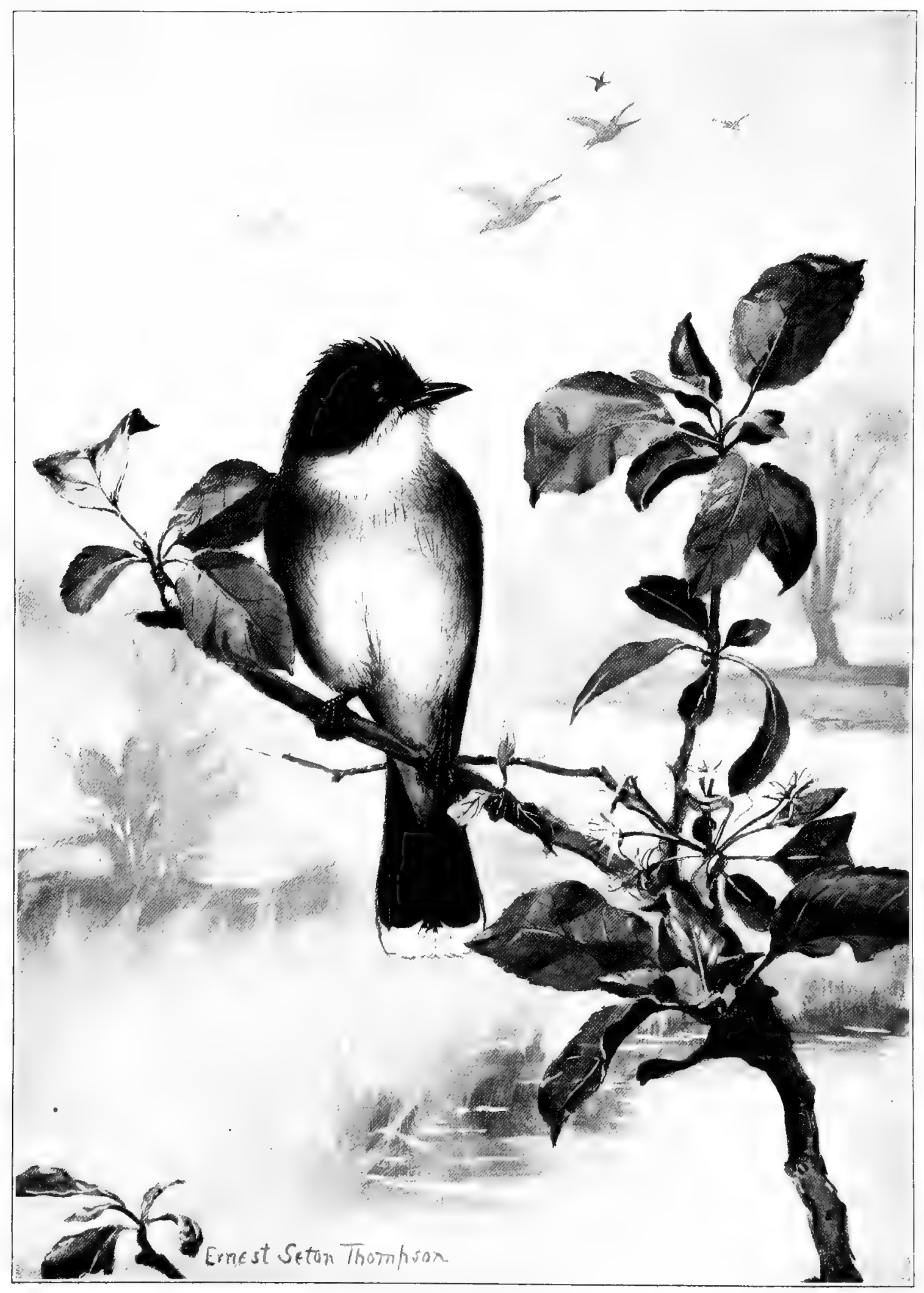

THE KINGBIRD 


\section{THE KINGBIRD}

THE swallows and swifts spend hours on the wing, turning to the right or to the left, upward or back, in pursuit of winged insects. Many other birds, notably the warbler family, take occasional flights after some insect which they have startled from the leaves. The habits of another large family of birds, the Flycatchers, are a compromise between these two methods of obtaining food. Selecting some post of observation, such as a dead limb, a fence, or the stalk of a stout weed, they wait patiently, keeping a sharp watch of the air about them. At sight of an insect flying near, they fly out in pursuit. If one is near enough to the bird, a click of its bill will announce the fate of the insect. The Flycatchers then return to the same or a neighboring perch.

The family is not, on the whole, very good-humored; in fact, they might justly be accused of irritability and pugnacity. The Kingbird, in particular, the head of the house, is noted for his constant attacks on any winged creature that approaches his nest. It must be admitted, however, that when nesting time is over, he lives very peaceably with his neighbors; but while the female is brooding the eggs or young, the excited cry of the male is constantly heard, and every Crow that comes in sight is pursued, sometimes for a mile. The Kingbird gets above his victim and darts down at its head; the Crow can be seen wincing at each vicious jab of the bill. One or two observers have actually seen the Kingbird ride on the Crow's back for some distance. The Kingbird has a patch of red concealed under the black feathers of his crown; when he 
is angry or excited, these red feathers blaze out. They are very rarely seen by men, but I imagine the Crows see them oftener than they like.

Apple trees in old orchards are favorite nesting places of the Kingbird, and no pains are taken to conceal the nest. It is composed of twigs loosely laid together, and often festooned with white strings or the dry, woolly heads of the mouse-ear everlasting. The inside of the nest is neatly lined with feathers, horsehair, or roots, and contains from three to five white eggs spotted with brown. The Kingbird is here from the first of May to the first of September, but like all strictly insectivorous birds, it must spend the winter far to the southward. The bird's only notes are the shrill cries, kipper, kipper, given singly or quickly repeated. In spring the birds often mount to a considerable height, uttering this cry continually, and apparently attempting, by this exhibition, to express the emotion common to all creatures at this period of the year.

The Kingbird is a very satisfactory bird to beginners; the color pattern is so marked and the bird is so fond of exposed situations that it is seen and recognized without difficulty. Except the Cedarbird, whose tail is tipped with yellow, I know no other small bird of the eastern United States whose tail feathers are all tipped with a regular edge of light color. The Kingbird is the bird most commonly seen from a car window; in almost every field, the mullein stalks or wire fences will display one or more individuals, their white breasts or black and white tails showing conspicuously in the landscape.

The Kingbird has often been accused of destroying honeybees. Even allowing that individuals occasionally do some damage in this way, the good services of the race in destroying harmful insects far outweigh these injuries, and the remedy is to drive the bird away from the hives, not to kill it. 



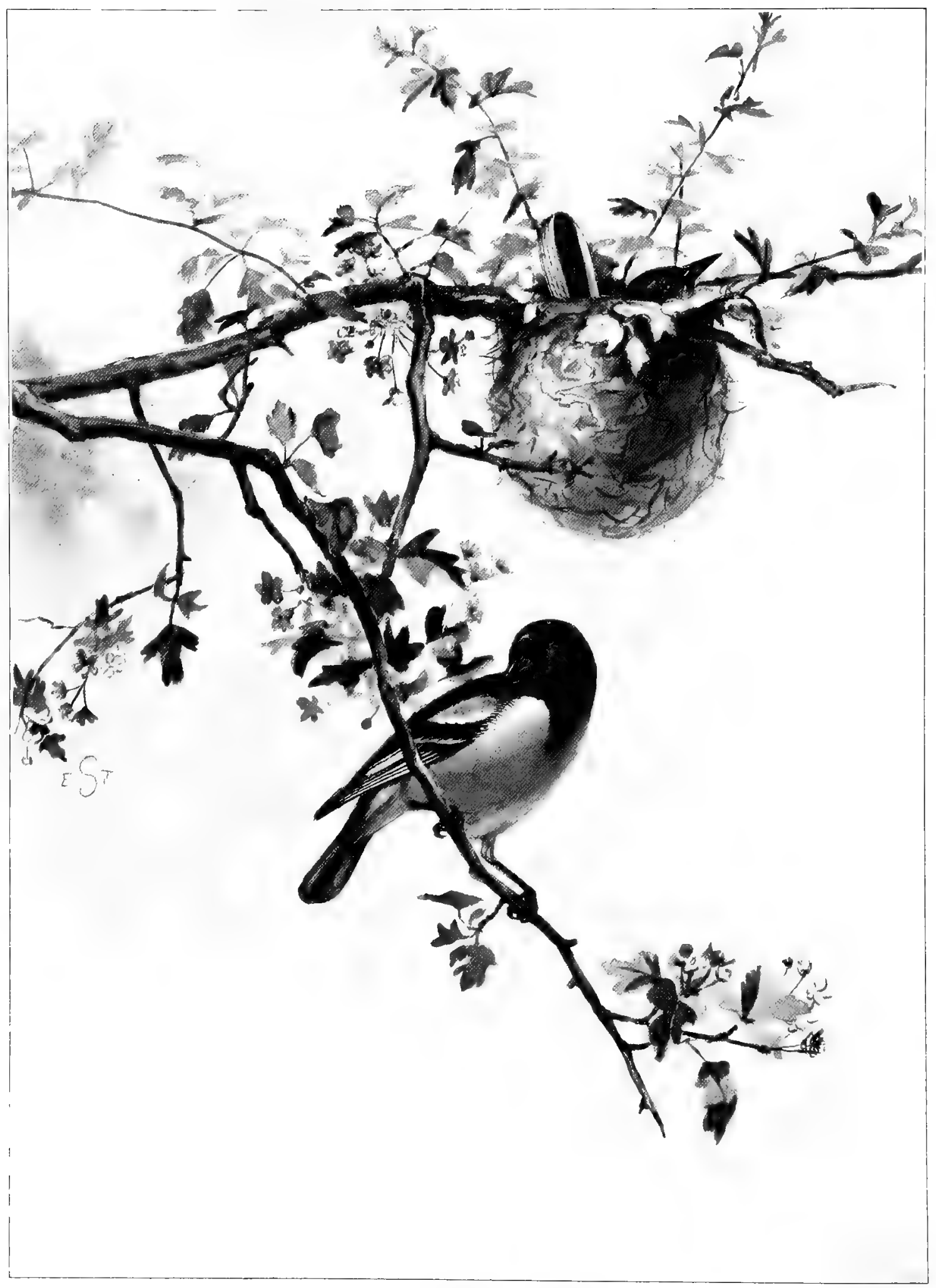

THE BALTIMORE ORIOLE 


\section{THE BALTIMORE ORIOLE}

THE arrival of the Orioles in the first week of May marks for many people the return of spring. The males come first and take possession at once of our streets and gardens, calling from the elms, or dashing into the cherry trees white with blossoms. The females arrive a day or two later, and the work of house-hunting begins soon after. In the selection of a nesting site, the judgment of the female alone is naturally allowed to have entire weight. The male is politely anxious, flying from twig to twig, as if recommending them; but the female knows that she must sit for days over her precious eggs, and be swung by all manner of storms, in whatever situation she finally selects; she means, therefore, to be sure before she builds.

The number of trees on which hang two nests, one evidently older than the other, is very noticeable, and probably means that the same pair return to the same tree to build. Many people have an idea that birds use the same nest in successive years, but it does not seem likely that such a skillful architect as the Oriole would patch up the old nest, when with a few days' labor she can build a new one, clean and strong, and very likely improved by her former experience. The materials used for the construction of the nest are tough, fibrous strips for the framework, and softer materials for the lining. The female often comes to the clothesline and twitches out some threads, and she is very thankful for twine or similar material hung out where she can find it. Lowell, who loved the Oriole next after the Bobolink, hung out gay-colored threads for his birds, and was rewarded with the sight of a brilliant nest. 
The female builds at first a framework of strong material, which is attached to the several twigs on which the nest hangs. She actually ties knots of this material with her long sharp bill, thrusting the end of the thread through a loop, then reaching over and pulling it tight. Tragedies sometimes occur during this process, the bird becoming entangled in her own thread and choking or starving to death. A bit of comedy is sometimes seen when the Oriole, returning to her half-finished nest, catches a Summer Yellowbird in the act of stealing some of the material. After the frame is completed, the Oriole works from inside, weaving the web from side to side.

By June, the young hatch, and now the male, who has hitherto had an easy time, becomes very busy bringing food to the young. In a few days, they become old enough to cry for it very vigorously, and this they do so incessantly that their peet-teet becomes one of the characteristic sounds of early summer. By the middle of July, the young leave the nest, and then for a week or two the whole family are met with in the country lanes, the children resembling their mother in color, but easily distinguished by their short tails and the general downy look about the head.

The male suffers an eclipse during midsummer; his cheerful whistle is no longer heard, and we should think that he had already left for the South, did he not resume his strain in August. In fact, he has been moulting; but, unlike the Tanager, he replaces his bright feathers by others as gay, and before he leaves us, he is as bright as when he came. The wild cherry trees are now a favorite resort for the whole family; but by the first of September, they leave the Northern States and return to Central and South America, where they lead a careless life till the approach of spring reminds them of the village elms a thousand miles away. 



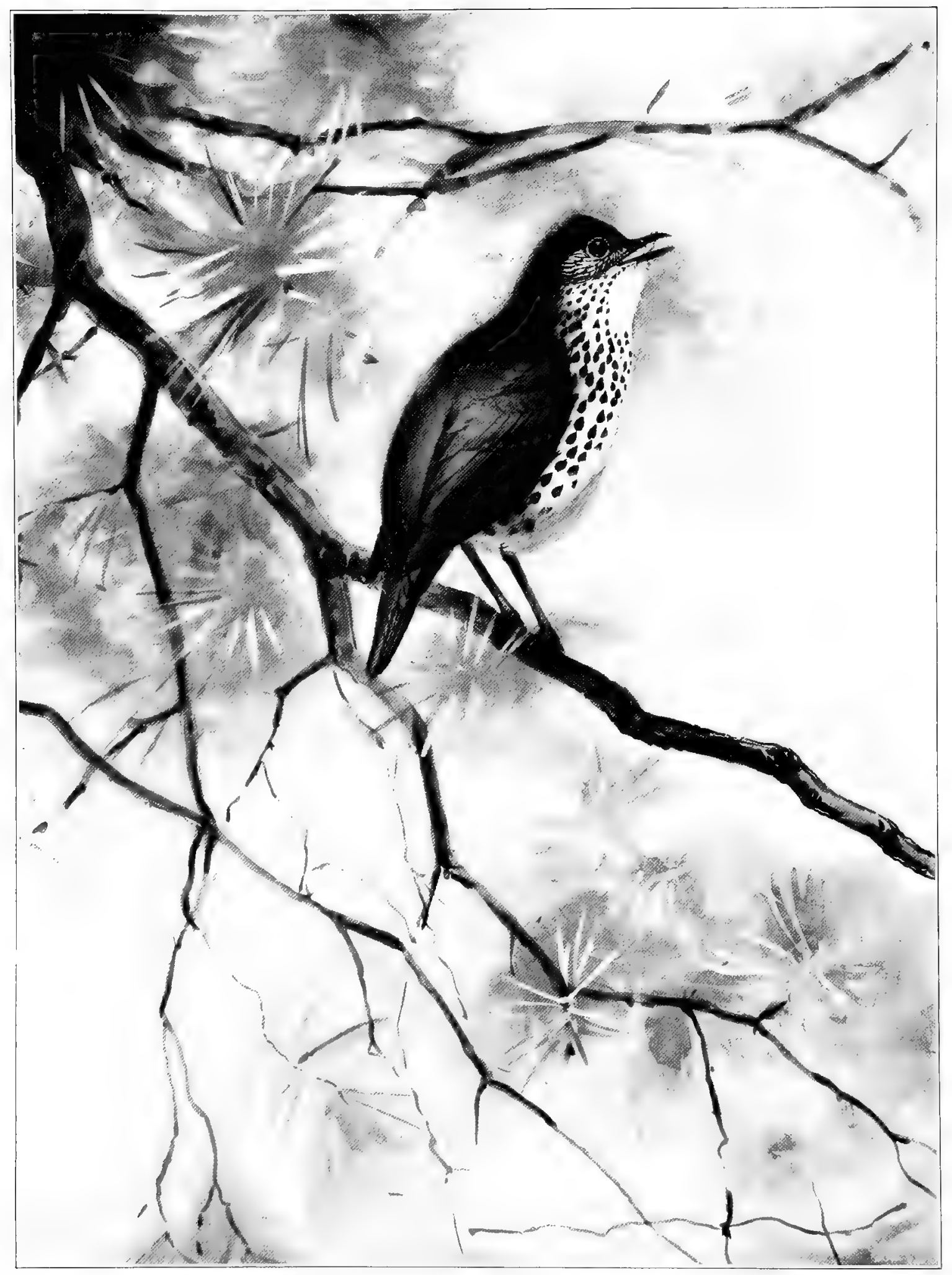

THE WOOD THRUSH 


\section{THE WOOD THRUSH}

IT is difficult to speak without enthusiasm of the song of a Thrush. He seems wholly to outclass all other birds. When a Rose-breasted Grosbeak, no mean singer as our birds go, has finished his song, let a Wood Thrush utter but a phrase of his strain, and the Grosbeak's warble seems commonplace. Except the Thrushes, we have few birds whose song appeals to the imagination as human music does. We listen curiously to the songs of the others, criticise them or comment on them, as we do on a landscape; but let a Thrush sing and we fall into a reverie, recalling sad, tender, or solemn ideas and associations.

The Wood Thrush and the Veery, or Wilson's Thrush, are the common Thrushes of all but the northern part of the Northern States. In the mountains, the Hermit Thrush is found. This bird is generally considered superior even to the Wood Thrush in the purity and solemnity of its cadences. It has one great advantage over its rival; it sings on mountain sides in clear, still air, so that the finest vibrations of its voice come to the ear with perfect distinctness. The song of the two Thrushes is readily distinguished by listening for the phrase ee-o-lee', with which the Wood Thrush regularly opens his chant. The Veery has received its name in imitation of its song, which resembles the syllables vee-ury, vee-ury, vee-ury, each phrase lower in the scale than the preceding.

The Wood Thrush arrives in the Northern States in May, and unlike the Veery, which is strangely silent on its first arrival, the male Wood Thrush announces his presence on the morning of 
his arrival, by chanting from some low limb his beautiful flute-like notes. In the Middle States, it is a common and almost familiar bird, building in the gardens even of large towns; but in wilder regions, it prefers copses, groves of young trees, and rocky glens, particularly if there is a stream near by. By the end of May the pair have finished their nest, which resembles that of the Robin, but is often composed of less coarse material and is generally placed in the fork of a sapling. The birds often take little trouble to conceal it, sometimes placing it close to a woodland path, and the passer-by becomes aware of its nearness by hearing the harsh, anxious chatter of the parents. The four eggs are blue like the Robin's. The Robin is, in fact, a near relative of the Thrushes, and the relationship is shown not only by the shape of the body and the bill, but by the spotted breast which the young Robins assume with their first plumage. In the Middle States, this relationship seems to have been recognized, as the Wood Thrush is there commonly called the Wood Robin.

While the female is brooding the eggs, the male may be heard day after day from some favorite perch, not too near the nest. The early morning and the late afternoon are the favorite times for all the Thrushes, but on cloudy days or in the cool shades of deep woods, they sing all day. Occasionally the song ceases for several days. Some calamity has befallen the nest; a squirrel or some other marauder has robbed the pair, and there are no more outpourings of joy, till with renewed courage they select some safer spot and build again. In midsummer, the Thrushes become very silent. Occasionally we come upon a group feeding in the cherry or viburnum bushes, but few are seen after August, and by November they are in the tropics. Only the nest filled with snow reminds us of the pair, whose return in May we await with impatience. 



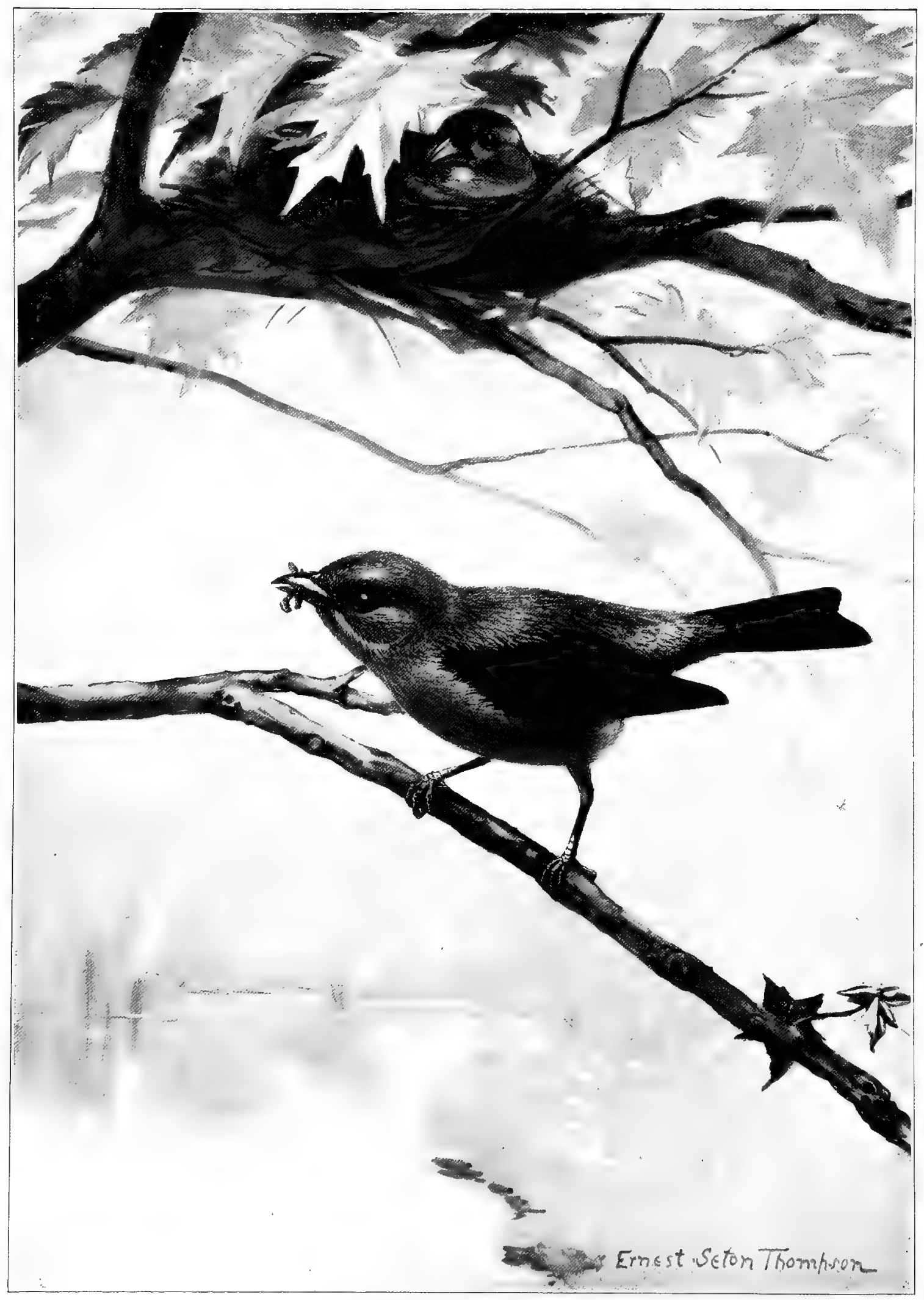

THE SCARLET TANAGER 


\section{THE SCARLET TANAGER}

IN South America, the Tanagers form a large family, but they send to the more northern of our Eastern States only one representative, the well-known Scarlet Tanager. A sight of this splendid bird properly, therefore, suggests the tropics. The Tanager is considered a rare bird, but it can always be found in suitable situations, and in certain parts of the country is really a common bird. Oak groves are the favorite resort of the bird, and since it does not often visit our dooryards, even in migration, and since we, as a people, do not often visit oak groves, the sight of a Tanager remains for most people a rare and exhilarating experience. The bird, too, is of a rather sluggish disposition, so that even if we visit the spot where a pair are nesting, they display only a rather languid curiosity. The call-note used by both sexes is well worth learning, for by its means our attention is often attracted to a pair which we should otherwise overlook; it consists of two syllables, resembling the syllables tschip, tschurr, uttered in a hoarse voice. The song of the male is such as a Robin with a cold might produce.

Either because the Tanager breeds generally at some distance from man, or because he considers that his brilliant coloring will make up for other deficiencies, the bird has never, as far as I know, done much to win the affection of bird lovers. They have enthusiastic praise for his coat, but little to say of his manners. A story which Wilson tells of a male Tanager is, however, a worthy exception to this statement. Wilson found a young bird which had fallen out of the nest and, having brought it home, put it into a cage with 
some Orioles. They altogether neglected the orphan, and as it refused to be fed by Wilson, the latter was about to return it to the woods, when a male appeared and tried to enter the cage. Finding this impossible, he went off, but returned with food and fed the young one for three or four days. At last, he showed so unmistakably his desire for the release of the young one that the owner set it free, and the two flew off rejoicing. If this Tanager was a type of his kind, the species need not fear the application of the proverb, "Handsome is that handsome does."

Tanagers arrive early in May, and may then be easily observed, as the trees are not yet in full leaf. Occasionally, in cold storms, all birds seem to keep near the ground, and on such occasions Tanagers are sometimes seen feeding on the ground itself, their splendid colors showing to wonderful advantage. The female is a very plain personage. Olive green above and greenish yellow below, with dull brownish wings, is a combination of color that serves very well to keep her concealed among the leaves. The nest is sometimes placed in orchard trees or even in low bushes, but frequently in tall oaks. It is loosely built of straw and twigs, and contains, by the end of May, from three to four eggs of a light greenish blue, marked with brown and lilac. The young are fed on insects gathered from the leaves. By the end of the summer, the male moults his bright red feathers and comes out in a suit resembling that of the female, but he keeps his black wings and tail. The whole family, clothed in these inconspicuous colors, migrate southward and remain in the tropics till the following spring. 



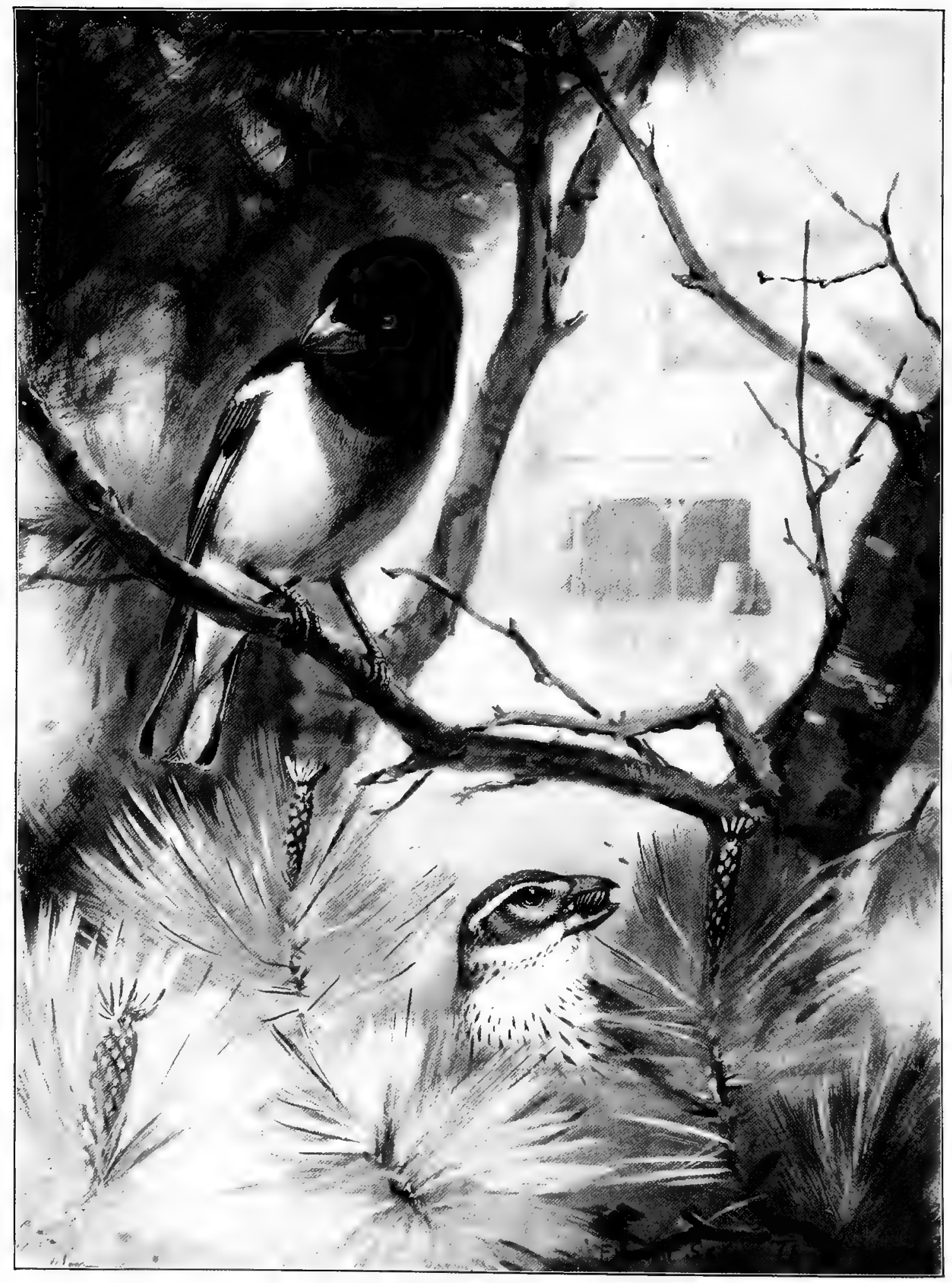

THE ROSE-BREASTED GROSBEAK 


\section{THE ROSE-BREASTED GROSBEAK}

To see a Grosbeak for the first time gives a student of birds almost the same feeling of exaltation as the first sight of a Scarlet Tanager. If one should hear, in the shade trees about the house, a Robin singing much faster and with a richer voice than ever before, and, after patient search, find the twig where the bird was singing, one's first thought would probably be, "Some escaped cage bird from the tropics." The head of the male Grosbeak is black, the tail and wings black and white, but in the center of the white breast is a triangle of pure rose, carried in some individuals far down the breast. When the bird flies, the white patches in the wings have a peculiar effect, like a circle of white. The large, almost monstrous bill, not only accounts for the bird's name, but explains why he is put into the same family with the sparrows. His nature, too, is eminently practical, as a sparrow's should be; a favorite food is the potato bug.

His mate lacks the black and rose, but her beak betrays her. She is not a particularly interesting bird, and does not even have the credit of excellence in household matters, at any rate as far as building her nest is concerned. It is made of a few coarse twigs loosely laid together, - a little platform through which the eggs sometimes show from below, and from which one would think they must certainly fall off. The nest is placed in a bush or low tree, and contains three or four greenish blue eggs, thickly marked with red. The young are out in July, and though a few Grosbeaks are occasionally seen in September, most of them have already left for the tropics by the end of the summer. The same joyous week 
of May which brings the Thrushes, Bobolinks, and Orioles brings them back again.

Just as a knowledge of the hoarse note of the Tanager will often betray the presence of that splendid bird, so an acquaintance with the sharp click, like that of a pair of shears, which the Grosbeaks make, will often attract the student and reward him with a sight of the beautiful rosy breast. Grosbeaks sing for a long time on one perch, - not on the uppermost spray of the tree, as that other tropical sparrow, the Indigo bird, loves to do, but, like the Tanager, on some branch well inside the canopy of leaves. In the first weeks of May, when birds of many species are mating, two and sometimes three male Grosbeaks may occasionally be seen pursuing each other, their white wing bars and spots making a showy contrast to the black. The victor in the struggle then returns to the tree near the female, and pours out a song of unusual vigor and sweetness. In May, the Grosbeak visits the blossoming fruit trees, snipping off the petals and the undeveloped fruit. Suspicion has therefore fallen on him, but it is now believed by the best authorities that this "budding" is not severe enough to injure the tree or the crop of fruit. Nor must we forget to throw into the other balance the result of his labors in the potato field.

When the adult male Grosbeak moults in summer, the rose on the breast becomes duller, and the black on the head and back is almost entirely replaced by brown. Like the Tanager, however, he retains his black wings and tail, and may thus be distinguished from the brown-winged young males. 



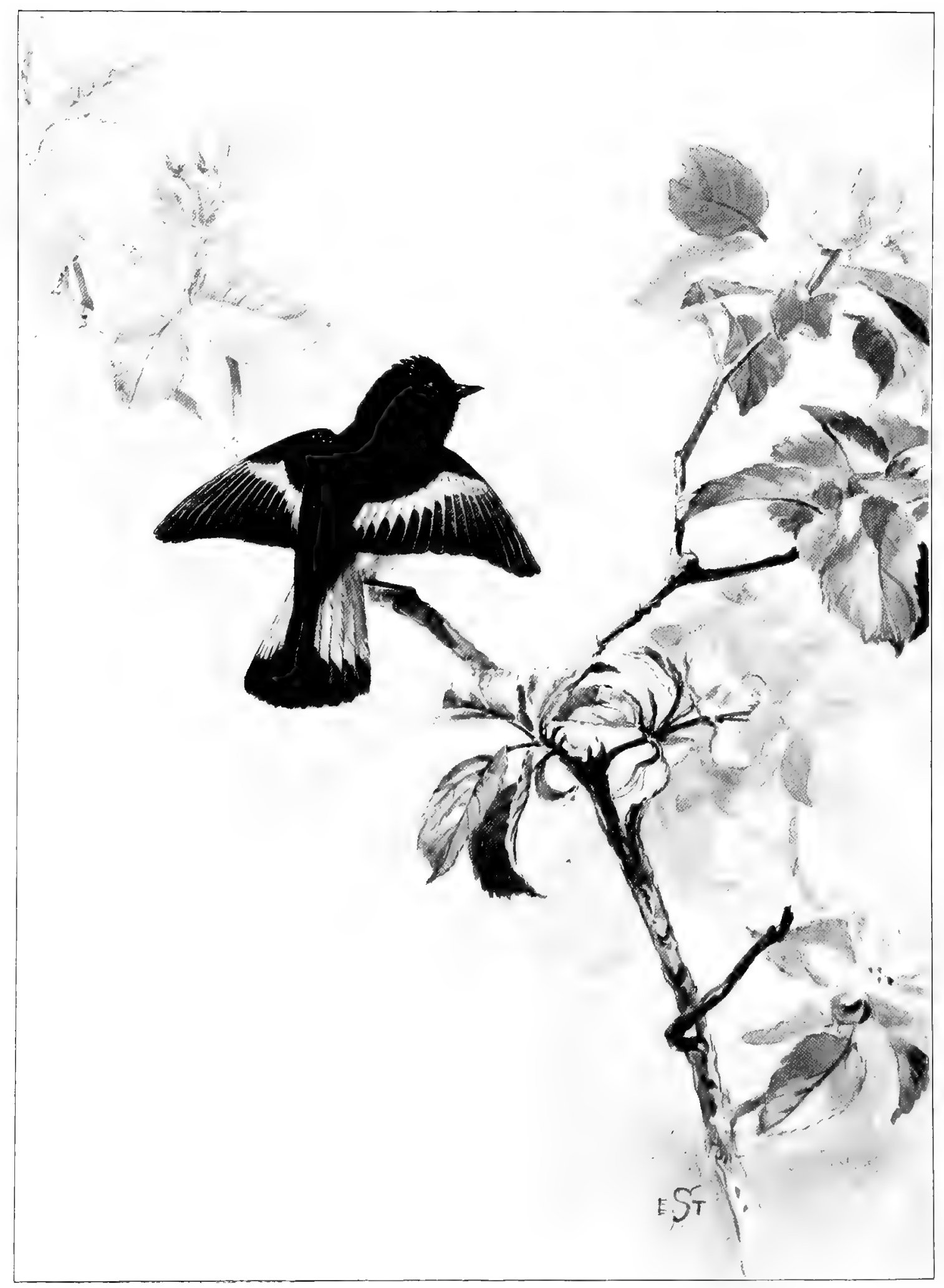

THE REDSTART 


\section{THE REDSTART}

Almost a fourth of the birds usually seen by a good observer in a morning's walk in May or June, belong to a family known as Warblers. If they were really as musical as their name suggests, people might know them better; but even as it is, their colors are often so bright that the birds well repay one who takes the trouble to make their acquaintance. Perhaps the best known of the family is the Yellow Warbler, not to be confused with the Goldfinch, from which the absence of the latter's black cap, wings, and tail will distinguish it. The Oven-bird, whose loud teach-er, teach-er, teacher is so common a sound in dry woods in summer, is another member of the Warbler family. The gayest of them all, however, in most parts of our country, is the Redstart. His coal black head, with bright orange patches at the shoulders, and yellowish bands across the wings and tail, suggest a miniature Oriole.

The Redstart is a splendid bit of color; in Cuba he is known, according to Mr. Chapman, as "Candelita," the little torch. Black and orange is a not uncommon combination of color among birds, and never fails to be effective. The Redstart, moreover, makes the most of his color by keeping both wings and tail spread, so that the yellow and orange is constantly displayed. He flits from one twig to another, spreading his little black-and-yellow fan, flying out, turning his black head and glowing shoulders toward one, and continually uttering a little song, not much in itself, and only full of meaning and association to the bird's friends, to whom it suggests leafy shade near brooks in the summer heat. 
The name of the family to which the Redstart belongs needs, perhaps, a word of explanation. It simply means that our Warblers are related to a family of European birds which have well earned their name, since the family includes the Nightingale and one or two other birds almost as musical. The name Redstart, too, is English, - start coming from the Anglo-Saxon word for tail. It was applied in England to a bird with a red tail, and since our bird has bright color in the tail, the name was transferred to it by the English settlers.

Many of the Warblers frequent the thick woods and are little noticed; the Redstart, however, often builds in the trees or shrubbery about the house, particularly if a brook or pool afford an abundance of insects. In the crotch of a sapling or on a limb, the female places a pretty nest built of bark and soft materials. The female resembles the male in the pattern of color, but the black is replaced by gray, and the orange by a faint yellowish shade. Males only one year old resemble the female so closely that the sharp little song often seems to proceed from the bill of a female; in reality it is a young male that is singing, one not yet arrived at the full splendor of his future gay plumage.

The Redstart is often victimized by the Cowbird, and one feels the imposition more keenly in its case than in that of almost any other bird, for we know that the big clumsy Cowbird is being reared at the expense of a whole family of these pretty warblers.

The Redstart comes early in May and stays through the summer. Some are seen even as late as October, but these are, very likely, birds which have bred far North, where the late summer did not permit them to rear their young so early as our own birds. 



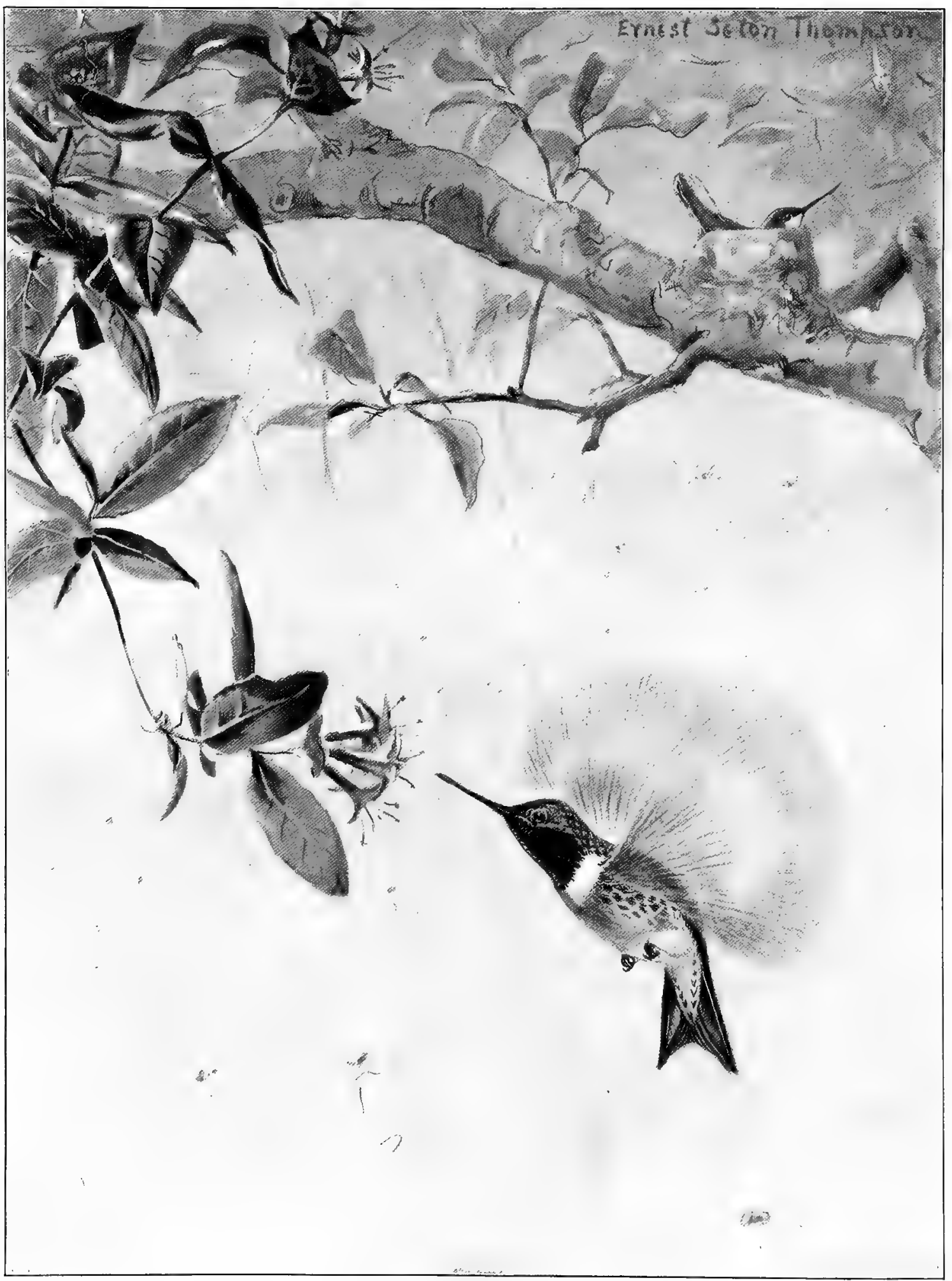

THE RUBY-THROATED HUMMING-BIRD 


\section{THE RUBY-THROATED HUMMING-BIRD}

THE restless activity and general appearance of the Hummingbird make one almost hesitate to believe that it is really a bird and not a brilliant tropical insect. It possesses no song; few people see it except on the wing, and its nest is so rarely found that to most people the bird is merely a sudden apparition, seen hovering over a flower, its ruby throat sparkling in the sun. When the Humming-bird's nest is discovered, it turns out to be a structure as delicate and rare as its little architect. It is often fixed on a lichen-covered twig, frequently in orchards, but as often on tall forest trees. To the outside of the nest, bits of gray lichen are fastened, so that at a distance the nest is mistaken for a knob of the twig itself. The eggs are always two, ridiculously small, like pea beans.

The Humming-bird is not a good father. He neglects all the domestic duties; being rarely seen near the nest after it is completed. The female brings up the two young birds unaided, feeding them by thrusting her long bill into their gaping mouths and pumping food into their throats. The process has been described as "a frightful-looking act." The food thus administered to the young consists, probably, of soft-bodied insects, for when Hummingbirds visit flowers, it is not only to gather honey, but also to capture the smaller honey-gatherers.

Many charming stories have been told of the fearlessness of the Humming-bird. It had often been observed that birds fed from flowers held in the hand, but it remained for Mrs. Soule to make 
artificial trumpet-vine flowers, and by filling them with sugar water, to provide a daily feast for her Humming-bird neighbors. Though the birds are very irritable and pugnacious when wild, frequently attacking each other with the shrill squeaks which are their only notes, yet, in captivity, they prove very gentle and almost affectionate. The Humming-bird has discovered another method of obtaining the sweet liquor which it loves. The Sapsucker, or Yellow-bellied Woodpecker, is in the habit of drilling rows of small holes into the maples of the northern forests, and sucking out the sap which fills these little wells. Many insects are attracted to the sweet fluid, and the Humming-birds also come as uninvited guests to the feast; so that while the Woodpecker is drinking on one side of the tree, butterflies, bees, wasps, and Humming-birds are fluttering about the other.

By the end of September, the season for honey gatherers is about over in the North, and the wings which can support the little body for so many seconds in front of a flower, now take it southward to the tropics, where there are always flowers. It is not until May, not until the red blossoms of the Japan quince are open, that the Humming-birds return.

The Ruby-throated Humming-bird is the only species found on the Atlantic coast; the female, however, lacks the ruby throat, and is sometimes taken for another species. Humming-birds seen at dusk, if caught, will prove to be, not birds but clear-winged or Humming-bird moths. In South America, however, there are over four hundred different species of Humming-birds. A museum case full of these is a marvel of beauty and interest; the iridescent colors of their gorgets, or throat-pieces, the variety of shapes which their bills assume, the development of their throat and tail feathers, give one the impression of a show case full of fantastic jewels. 



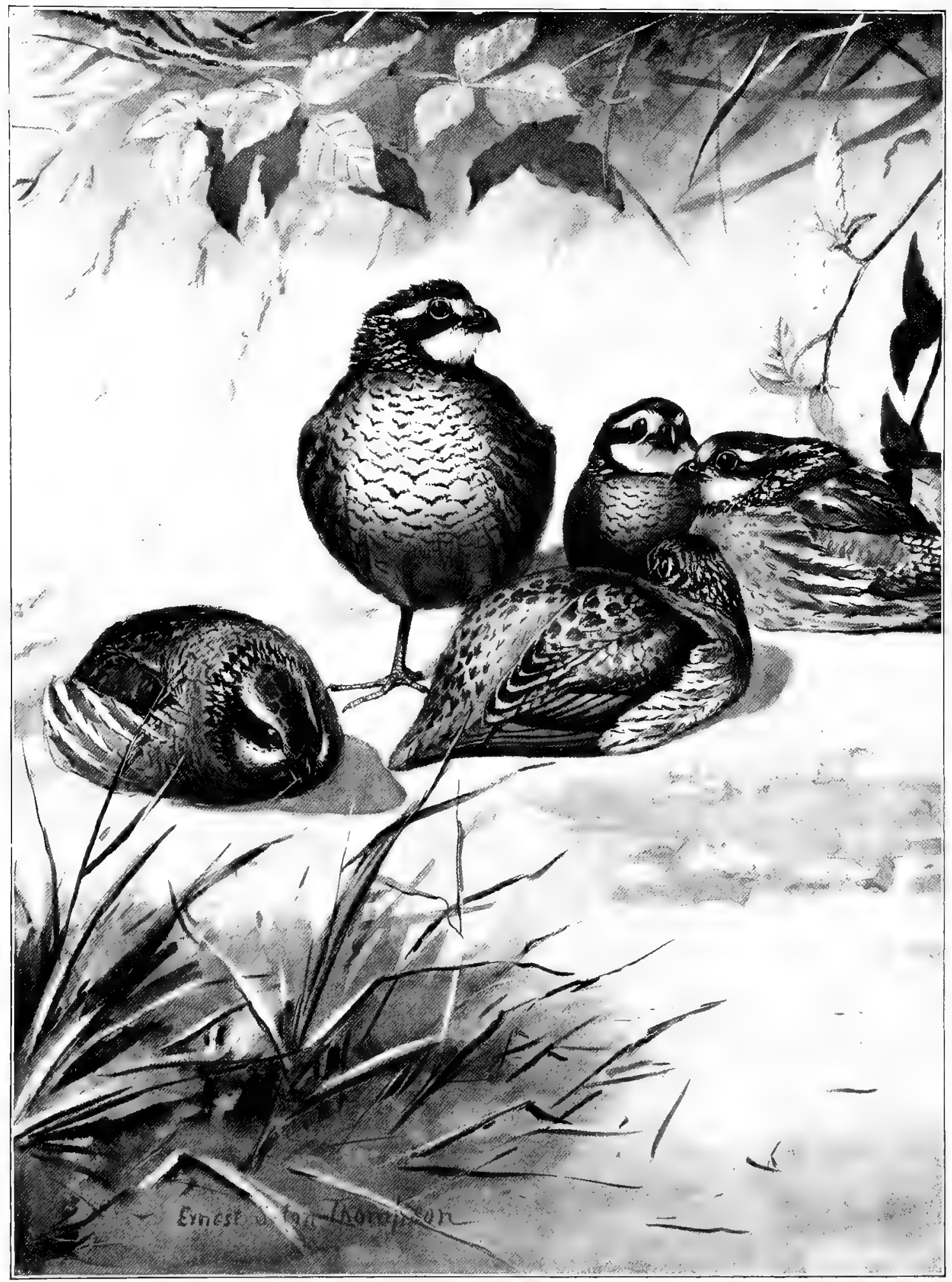

BOB-WHITE 


\section{BOB-WHITE}

BoB-white, unlike the majority of our birds, does not migrate southward in winter; the whole covey, unless they are killed, spend the whole year near the spot where they were born, feeding on the fallen grain, seeds, and various kinds of fruit. In hard winters, they become very tame, and if fed regularly, come to the barnyard almost like poultry. Most people are only too familiar with this bird, but not as he looks in life. Then he is full of energy and spirit; his pure white throat shows against the black of his head, and his rich reddish brown wings are ready to carry him off with a whirr that startles one. For one that we see alive, we see a thousand hanging, bloody and bedraggled, in the markets. Few people who become really acquainted with Bob-white, who see him sitting on a stone wall calling his name, or see his mate hurrying her little ones over the road into the blackberry vines, will care to make another meal off his little body. We must consider not only the wrong, if we acknowledge it to be one, done to the individual quail whose life has been taken, but the danger that threatens his whole race. The cheerful Bob-white is already a much rarer sound than it used to be, and the bird has many other dangers to contend against besides the pot-hunter's gun.

The greatest peril that besets quail in the North is the occasional midwinter blizzard, followed by intense cold. The quail at night huddle close together on the ground, their tails touching and their heads pointing out in a circle. After a great storm in a recent winter, the melting snow exposed a circle of quail, surprised 
and buried by the snow, like the people of Pompeii buried under the falling ashes.

In May, the male begins to whistle the two or three clear notes which have been translated into "Bob-white," or "More wet." This call is not only a summons to the female, but also a challenge to other males; if one hides near by and imitates the whistle accurately enough, a sudden flight will sometimes bring the angry bird directly to the spot. The surprise of the visitor is then amusing enough. Stone walls, fences, the low limbs of trees are favorite perches for the male, and his cheerful call has long been a familiar sound in farming country, from Massachusetts southward.

The nest is placed in some tangle of blackberry vines, along the edge of a field, and is a sight worth a long journey to see. The pure white eggs, often as many as fifteen, are laid close together in such a manner that the little body of the female may cover and warm them all. When the young are hatched, they are covered with down, and run at once, like chickens, and unlike the little blind naked young which we see in the nests of song birds. They follow their mother through the tangled grass or low bushes, feeding on fruit and insects, and later on the grain in the stubble fields. The whole family keep together, even when the young are able to care for themselves. When they hear any danger approaching, they keep close to the ground, relying on their brown coloring to conceal them. If the danger comes too near, they are off in half a dozen directions, over walls and bushes, coming quickly to earth again when they see some sheltering covert. Then, after an interval, one hears a note something like a guinea hen's, issuing from different parts of the field. Guided by these sounds, the whole covey reassemble. 



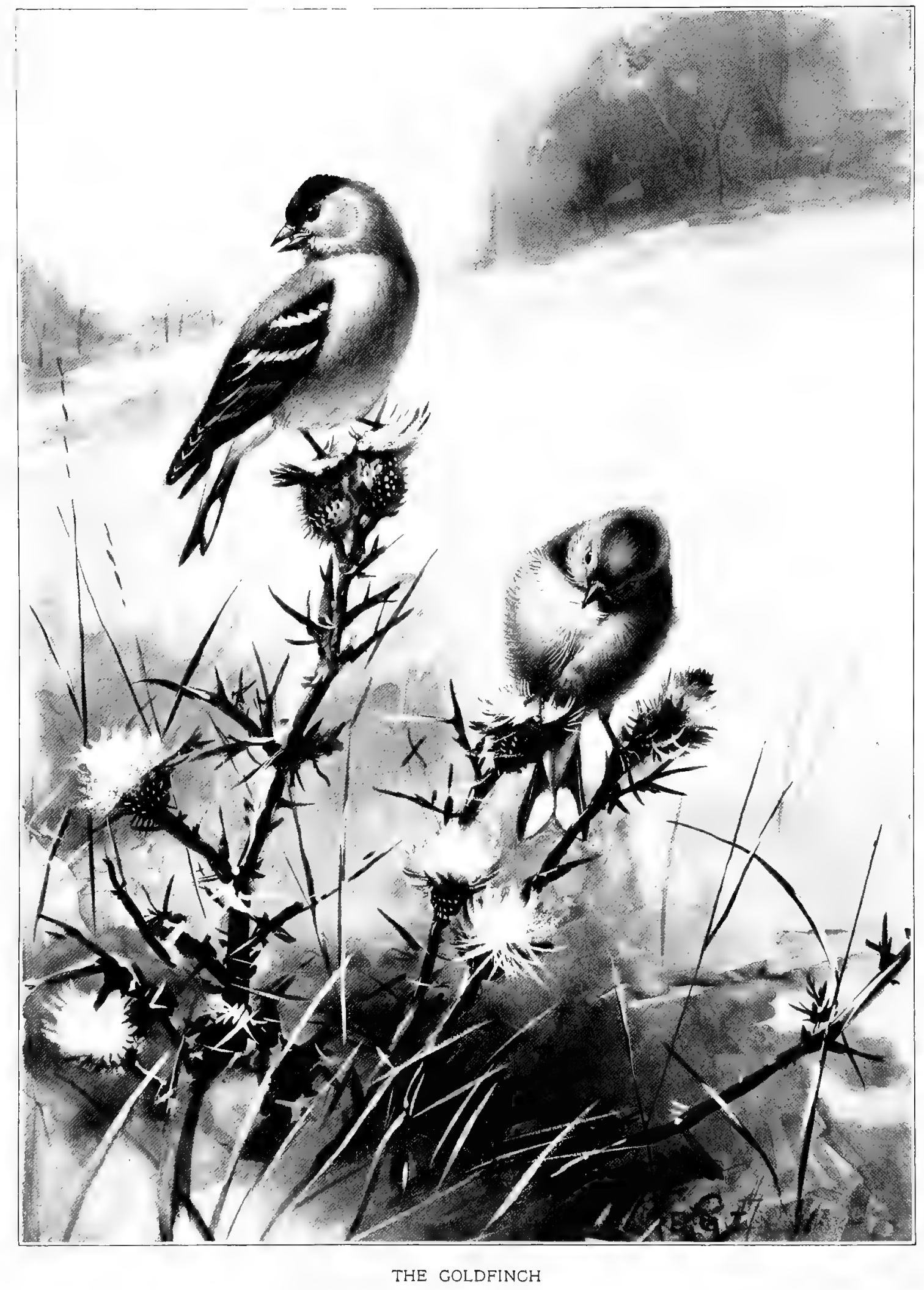




\section{THE GOLDFINCH}

Nor the most sullen sky nor the bitterest cold seems to discourage Goldfinches. They are always cheerful and affectionate, keeping together for the greater part of the year in larger or smaller flocks, which call to each other, if separated, by notes as sweet as those of a Canary. In summer, Goldfinches find an abundance of food in the seeds of many species of plants, but in winter also many remain even in the Northern States, searching cheerfully among the dry weeds and grasses, and uttering their sweet notes. Many people, however, do not notice them at this season, for when winter comes the head and body of the males of this species, as of many others, lose the bright black and yellow which marks them so distinctly in summer, and are clothed in dull brownish shades. About the first of April, one notices here and there in a flock a male that shows a few bright yellow feathers, and by another month, they have moulted their winter dress and are as gay as ever.

In the spring and early summer, the Goldfinches are extremely musical, spending hours in uttering a simple but pleasing song. Several males now engage in what seems to be a musical contest, flying out from a tree and circling about with set wings, all the time keeping up a continual strain. When flying through the air at a considerable height, they go in long curves, and utter during each undulation three or four simple notes. As they seem constantly to have business in one part or other of the country, the wave-like flight and characteristic notes become a common feature of the summer landscape. 
Though the Goldfinches are here all winter, they delay nesting till very much later than the other resident birds; the Chickadees have their first brood already out in the world by the time the Goldfinches determine on building. The female is a modest-colored little body, as is often the case where the male is bright. The pair generally build in July, and choose some thick leafy tree, often a maple or poplar, and there, on a limb at a considerable height from the ground, construct a very neat nest, deep and cup-shaped, built of fine materials and lined with down from plants like the thistle. Here five or six bluish white eggs are laid, and when in another month the young Goldfinches begin to fly, it is at once evident from their sharp, insistent crying. As the calling of the young Orioles is a mark of late June, so the notes of the young Goldfinches become associated with August.

Goldfinches are very fond of the seeds of many kinds of composite flowers; they bite holes in unripe dandelion heads and take out the seeds; thistles are another favorite food, and a row of sunflowers planted in the garden will not fail to attract them. In winter, besides the seeds of weeds, they feed on birch seeds, scattering the scales over the snow, and they even pull out the seeds of the pitch pine, when the scales begin to loosen toward spring.

No bird has livelier, more cheerful ways than our Goldfinch, and none becomes a greater favorite. People are often at considerable pains to remove the dandelion plants from their lawns; if the gay flowers themselves do not repay one for their presence, many would certainly allow them to remain in order to have the pleasant spectacle, in summer, of a flock of yellow Goldfinches scattered about the grass and feeding on the seeds. 



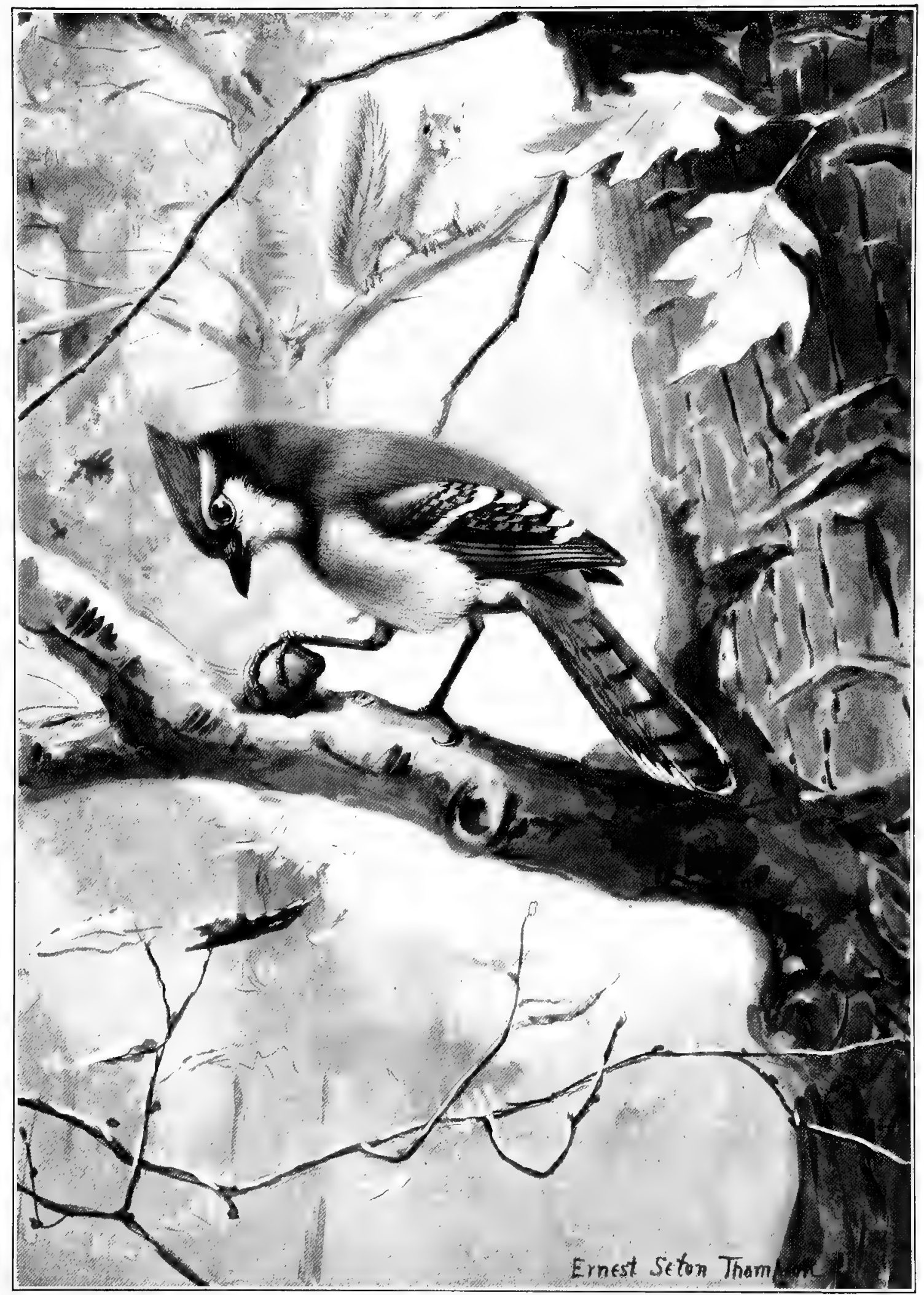

THE BLUE JAY 


\section{THE BLUE JAY}

Most people are surprised when they first learn that the Blue Jay is a near relative of the Crow. The difference in color is certainly marked, but in other ways the resemblance is striking. Neither bird can utter its most characteristic note without gesticulation. Watch a Crow from a car window when the caw is inaudible, and the bowing and opening of the wings are all the more noticeable. The motions which the Jay makes when screaming are not so well known, as the sound generally comes from a screen of leaves. Both birds are thieves and seem to relish their thieving life; both can live on almost any food; both are heartily hated by their neighbors in bird world. The Jay is more bitterly detested by the other birds than the Crow. He is himself suspicious, and at the approach of a hawk, owl, or man, warns the woods by his cries. Besides the ordinary djay, djay, the loud scream so familiar in the autumn woods, the Jay has other cries; a note like a wheelbarrow turning on an ungreased axle, a high scream exactly like the Red-shouldered Hawk's, and such a variety of lesser notes that one never is surprised to find that any unusual sound heard in the woods is produced by the Blue Jay.

Though one of the noisiest of birds when pursuing an intruder, the Jay has learned to slip through the trees without a sound, and conceals its bright blue and white in a remarkable way. A pair of Jays may be nesting in some evergreen in our very garden, and unless we happen to see the female slip into the tree, we may remain entirely unaware of their presence. The nest is roughly constructed of twigs and roots, and is placed in a tree from six to twenty feet 
from the ground. On a lining of finer roots are laid four or five brownish or greenish eggs, spotted with yellowish brown. The young are hatched by the middle or end of June.

The Jay in spring is undoubtedly a reprobate. He cannot resist the temptation to sneak through the trees and bushes, and when he finds a nest of eggs temporarily left by its owner, to thrust his sharp bill through the shells; even young birds are devoured. In the autumn, however, the Jay is a hearty, open fellow, noisy and intent on acorns and chestnuts. The woods ring with his loud screams, as he travels through them with his companions. It is amusing at this season to observe them obtaining chestnuts, a favorite food. They drive their powerful bills into a nut and wrench it out of the burr, then fly off with it to a convenient limb and hammer it open. Many Jays spend the entire winter in the northern woods, subsisting on nuts, but the large numbers observed in the fall are evidence that many others are moving southward, where food is more plenty.

Jays and squirrels are curiously associated; both live in the autumn and winter, innocently enough, on nuts and acorns; both, in spring, poach on the eggs and young of birds. One becomes fond of each of these rascals in spite of his undoubted villanies, and is glad that though neither Squirrel nor Jay is protected by law, and in some states both are constantly persecuted, neither seems to be diminishing in numbers.

In Europe, the Crow and the Jay have several relatives, many of whom, such as the Magpie, Rook, and Jackdaw, share the family characteristics. They are all thieves, clowns, and impudent fellows, and yet win, if not affection, yet a certain degree of good-humored toleration. 



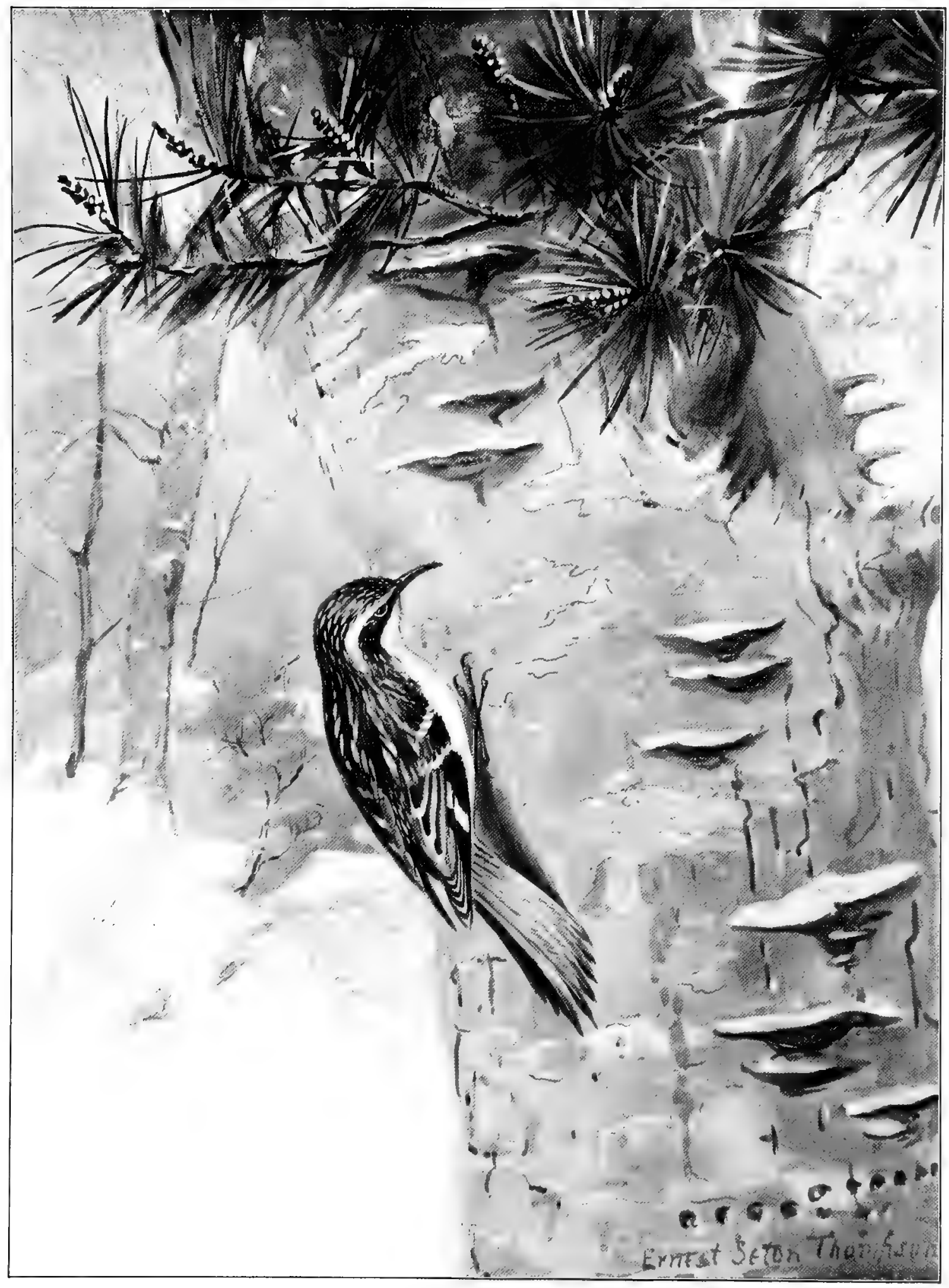

THE BROWN CREEPER 


\section{THE BROWN GREEPER}

In the bands of little birds which in winter visit the trees about the houses, there are often three different species, all of which find their food on the trunks or large limbs of trees, but by such different methods that a study of their habits is not only interesting but also extremely instructive. The little Downy Woodpecker, like all its tribe, hitches up the trunk or along the upper side of the limb, using its stiff tail feathers as a support, and holding on to the bark by its two pairs of sharp claws. The Nuthatch, with a short weak tail, and toes arranged as in all song birds, three in front and one behind, has the toes, however, spread so wide that it can climb head downward, over, under, or around the limb. Least known of the three is the Brown Creeper. It, too, has three toes in front and one behind, but although not related to the Woodpeckers, it has developed stiff and pointed tail feathers. It therefore clings to the bark in an upright position, and it commonly begins at the bottom of the tree and works steadily upward, often in a spiral.

During the winter months, the Brown Creeper probably visits every village street and every city park in the Northern States, but as it is just the color of the weathered bark and moves close to it, it escapes the notice of nearly every one. If one learns to distinguish the fine wiry note, and watches the tree from which it proceeds, one sees the bird flutter to the base of a neighboring tree and begin again its steady ascent. When two birds are together, they sometimes indulge in a very pretty flight, and tumble in the air like pigeons. As a rule, however, the Creeper is solitary, and, in this 
respect, offers a marked contrast to its companions and relatives, the sociable Chickadees and Kinglets.

The eyes of a Creeper are so near the bark which it is inspecting, that it is not strange that it finds food where we should look in vain. It has, besides, a very long curved bill which will reach into crevices in the bark, and before the end of the winter, it has undoubtedly stripped the trees of a large proportion of the dormant insects and their eggs, especially as, like the other winter birds, it seems to have a very regular beat, visiting the same groups or rows of trees every day. Few birds are so strictly arboreal as the Creepers. The writer has only once seen one alight on the ground, when the bird flew to a little stream to bathe. In the ice storms which occasionally clothe every trunk and limb with a glassy covering, the Creeper has to confine itself to the leeward side of the trees. Occasionally the Creeper, on account of its practice of beginning at the bottom of the trunk, flies to a spot on the tree below the band of tarred paper, which protects the shade trees from the visits of the canker-worm moth. On reaching the band, the bird makes a circuit of the trunk, in a vain attempt to find a passage. It is better provided, however, than the wingless moths, and when the circuit has been made, a short flight carries it over.

In April, the Creeper leaves its winter quarters for the North, and joins many other species in the great spruce forests of northern New England and Canada. Occasionally, on warm mornings before its departure, the male indulges in a little song, of the thinnest quality imaginable. When the pair reach their northern home, they hunt for a crevice under some great flake of loose bark, and there construct their nest. The bark of trees, therefore, furnishes the Creeper with a cradle at birth and a home for the rest of its life. 



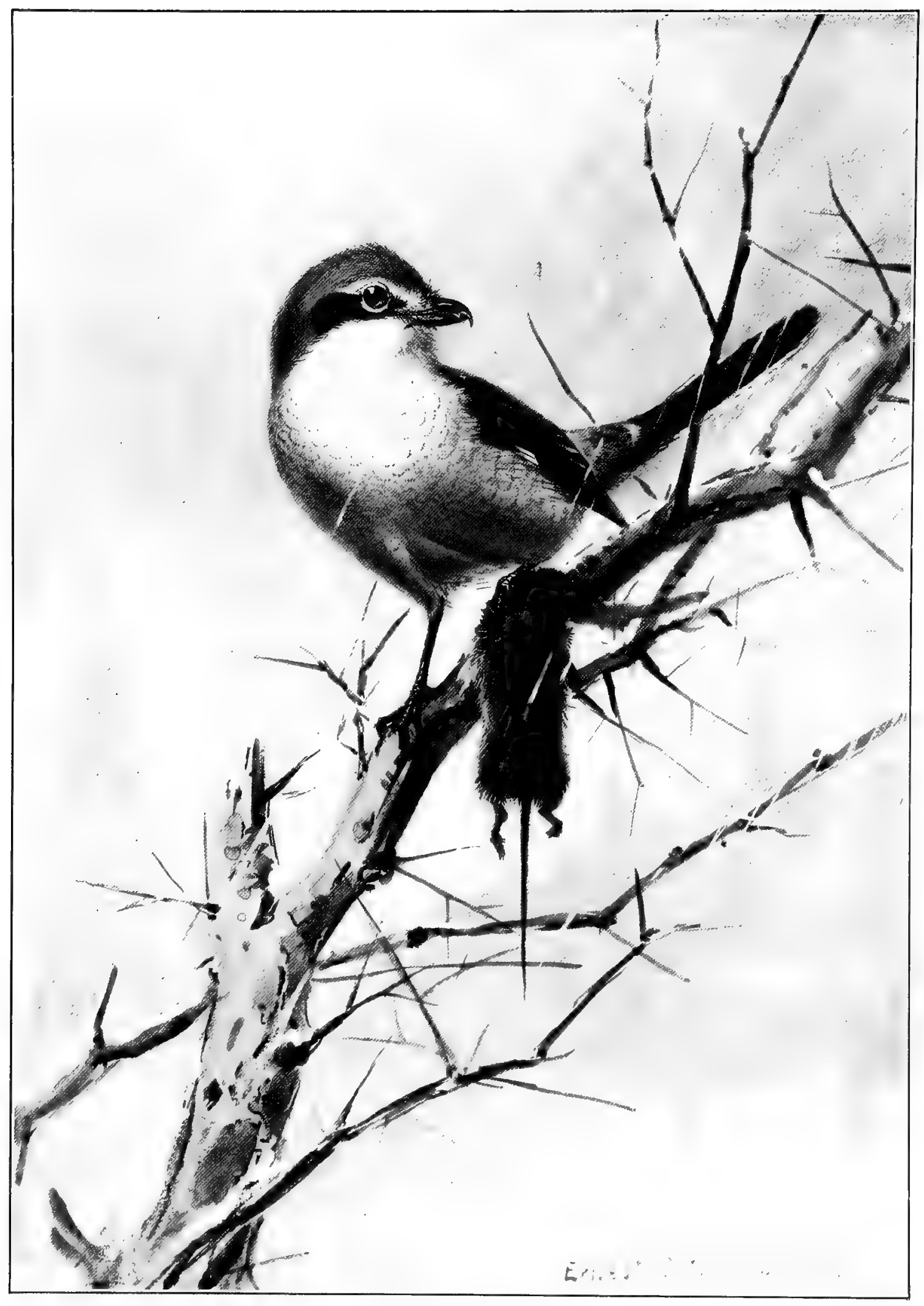

THE BUTCHER BIRD 


\section{THE BUTCHER BIRD}

EVERY one who observes the habits of birds soon notices with astonishment the regularity with which they return each summer to the same spots to breed. This is perhaps not so strange in the case of breeding birds; they may be so fastidious in their selection of food or of a nesting site that only a few places suit them, or the spot where they bred one year may appeal to their affection and so be selected again. It is no less evident and more remarkable that birds that spend only the winter in our neighborhood often have as well defined a home as those that spend the summer. Every autumn, about the first of November, if one looks carefully at the topmost twigs of the small trees that are scattered about the edges of some marsh, the eye may finally catch, perched on the very top, the figure of a plump gray bird, with black wings and tail, about the size of a Robin. Its tail often moves as if the bird were balancing itself. A nearer view would show that its bill was stout and slightly hooked, like a hawk's. Among song birds, it is our largest regular winter visitor, and will remain near the same spot till the end of March, when it retires northward to breed. The same trees serve year after year as look-out posts; no doubt the bird remembers where to find the fattest mice and grasshoppers.

The Butcher Bird, or Shrike, is one of the few birds that seem to have developed a sense of humor. I have seen it attack and drive off birds far larger than itself, apparently out of simple mischief. It often indulges in a succession of strange noises, some of which resemble the song of the Catbird, but the whole performance 
is interspersed with chuckles, squeaks, and harsh sounds, or interrupted by a grating cry, so that it can make no pretense to be called mèlodious. It seems sometimes as if the bird were simply amusing itself.

For a while you will regard the Butcher Bird as a good-natured, good-looking fellow; it is not till you find, near its post of observation, mice or birds jammed into the crotches of twigs, or discover a thornbush decorated with grasshoppers and caterpillars, that you recall certain unpleasant reports about its character. When you finally see it dash into a flock of sparrows and hear their screech of terror, or see it tear out its victim's brains with that hooked bill, you will understand its hawk-like habit of sitting where it can survey its whole domain. The Hawks clutch their prey in their curved talons, and then tear it with their beak. The Shrike's claws are neither curved nor powerful, so that it is evident that it wedges its victims into forked twigs or impales them on thorns, so that it can then tear off portions to devour. But why it so often leaves them uneaten (the practice of thus displaying its wares has earned the bird its name) has never been satisfactorily explained. Perhaps the bird means to return to them in times of scarcity, but they are so often left uneaten that it seems probable that it has formed the habit of hunting and hanging up its game, often with no thought of eating it.

The Butcher Bird has often been persecuted for the destruction of smaller birds; it seems far wiser to protect it, not only in order to preserve so interesting a bird, but because birds form so small a per cent of its food. In the spring and fall, it lives very largely on insects, and throughout the winter, mice form a large part of its diet. There is always danger of blundering when man interferes in the concerns of nature, and if he once exterminates any creature, it is beyond his power to re-create it. 



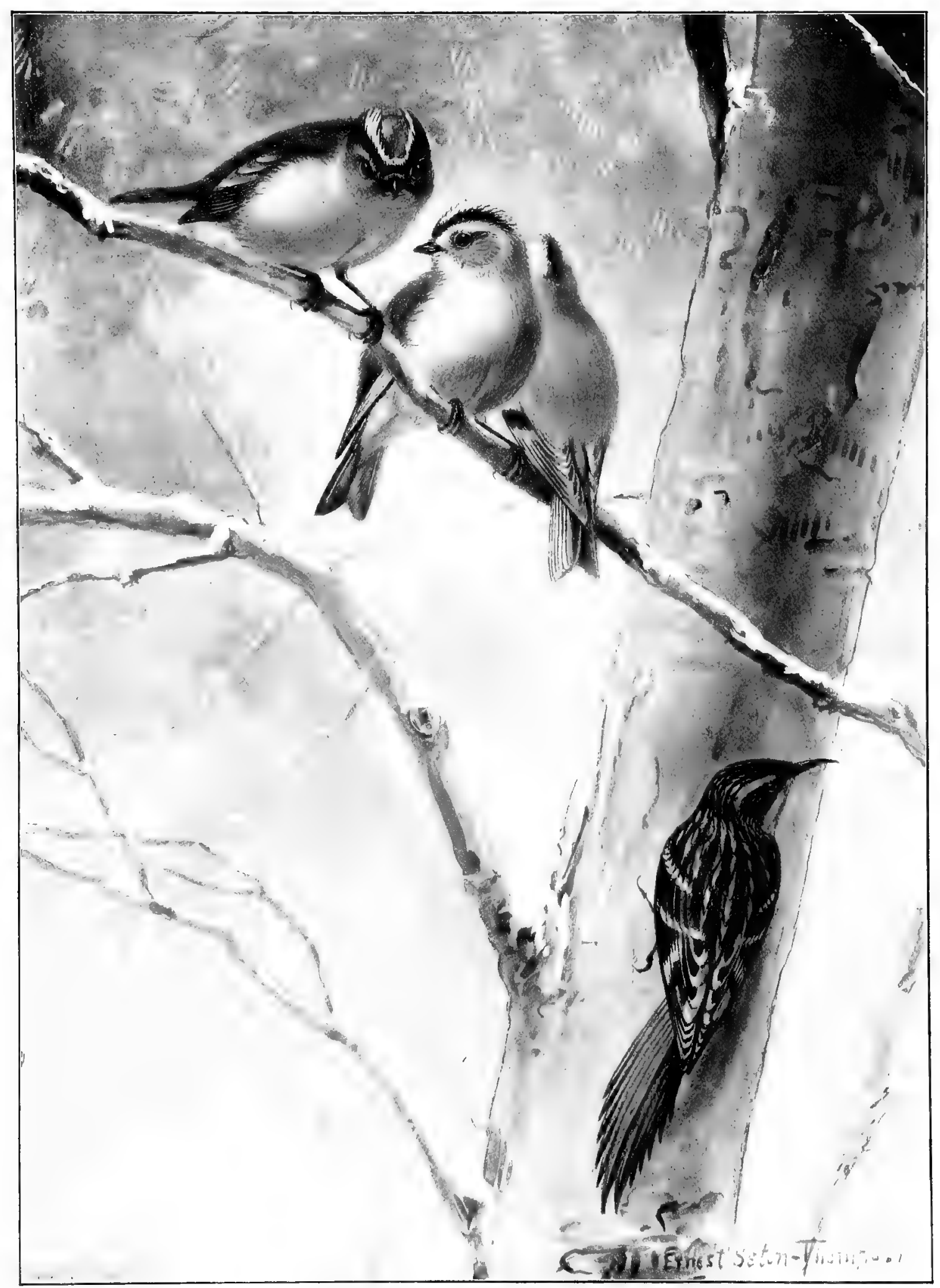

TIIZ COLDEN-CROWNED KINGLET AND BROWN CREEPER 


\section{THE GOLDEN-GROWNED KINGLET}

The Golden-crowned Kinglet is, next to the Humming-bird, almost our smallest bird, and it frequents thick evergreens so continually that it is rarely seen. There is little in its voice and habits to attract attention, and its activity and restlessness are so constant that we rarely catch sight of the bit of color which it possesses, the crown which the little king carries. But if we train our ear so that it catches every fine natural sound, no matter how trifling, we become aware some crisp winter day of a thin see, see, see, often repeated from some hedge, or group of orchard trees. If we watch, our eye will catch sight of one or two tiny creatures, flitting restlessly among the twigs, keeping their wings in almost constant motion, even when not actually flying. The general color of the bird is a shade known in the books as olivaceous, but the effect outdoors and at a distance is a dark gray; across the wings there are little whitish bars, and over the head dark lines enclose the little crown, - yellow in the female, orange in the male.

If we succeed in attracting the Chickadees to our trees, by tying up bones, the Kinglets often come in their company, but their little bills are too weak to pick at the frozen gristle, and they merely glean from the twigs and buds. The little scale insects, the eggs of moths and spiders, all manner of minute objects, are detected by their sharp eyes and seized by their skillful little bills and tongues. At night, the band retires to some thick evergreen hedge or grove, ready the next morning to resume their busy rounds. In April, the male is moved to utter a simple little song, and by the end of the month 
the whole company move to the spruce forests of the North, not to return to us until the next September.

In the Northern States, the Golden-crowned Kinglet is the only species that remains all winter, but from Virginia southward its cousin, the Ruby-crowned Kinglet, is associated with it; in summer, strange to say, the more Southern winter species goes farther North than the Golden-crowned, breeding from northern Maine to the frigid zone. A few years ago, no eggs or nest of either Kinglet had been described, but when they were at last discovered, they proved as dainty as the little builders themselves. The nest is globular, with an entrance in the upper part; it is placed in a thick mass of spruce twigs and composed of hanging moss, ornamented with bits of dead leaves, and lined chiefly with feathers. In such a nest, as many as nine eggs are often laid; imagine the little Golden-crown brooding in this bower.

Like some of the Warbler family, the Kinglet does not let an insect escape, though it should take wing before it could be seized. The bird, too, has wings, and darts out after its prey. In winter, it often hovers under the piazza roofs, or the lintels of the barn door, and while in the air, picks off the eggs or chrysalids that have been hidden in the crevices. Occasionally one of the birds, in its eagerness to seize some attractive morsel, flies sharply against a windowpane. No doubt it is the part of a thrifty householder to sweep out the insects from his piazza roof, but there are some, like Lowell, wise enough to leave a few decayed limbs on their apple trees for the Woodpeckers, a patch or so of weeds for the Snowbirds, and a chrysalis or two for the hungry Kinglets in winter. 



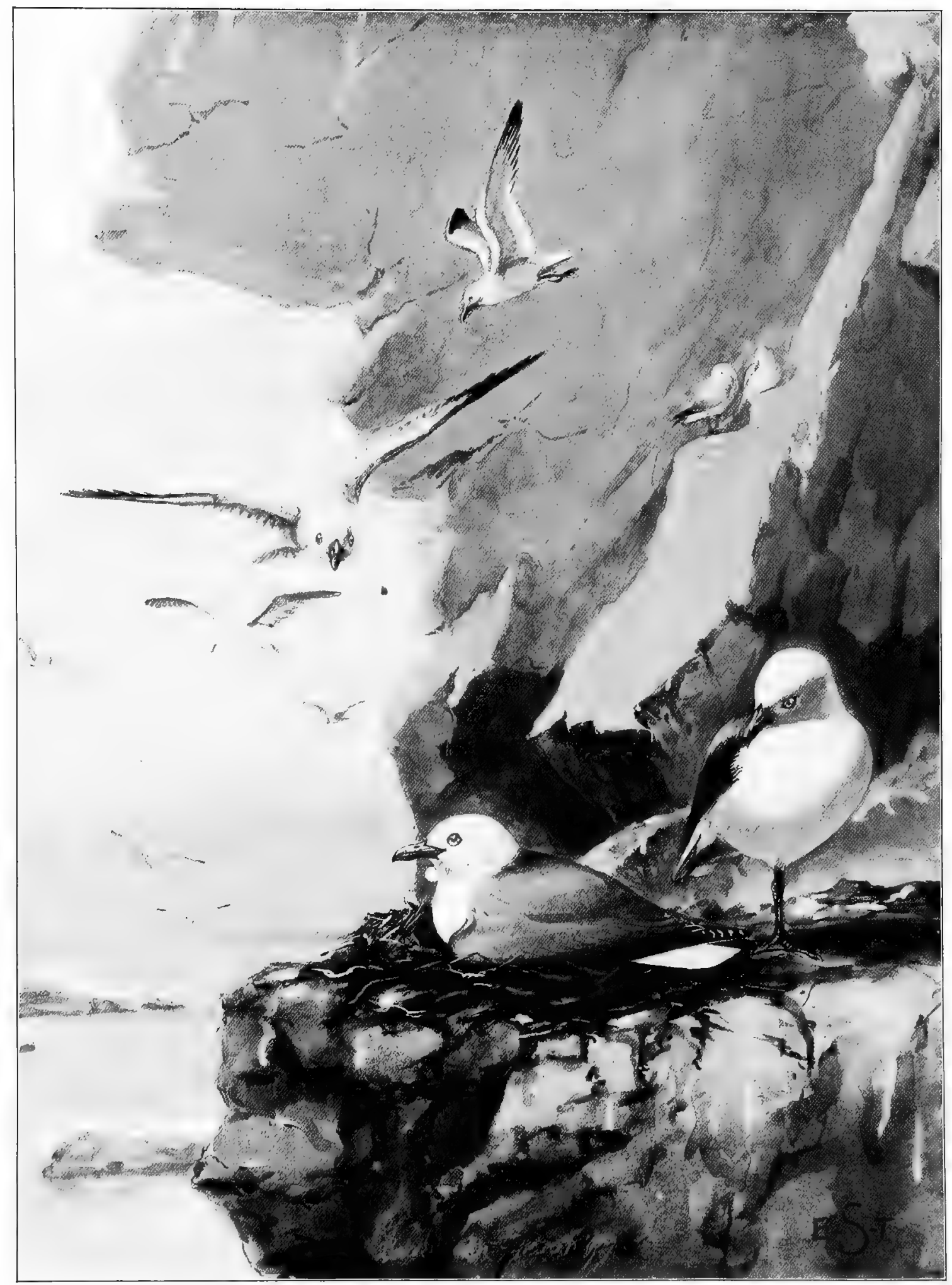

THE HERRING GULL 


\section{THE HERRING GULL}

All winter, a traveler along the seashore sees the great gray gulls wheeling gracefully through the air with outstretched wings, floating lightly on the water, or sitting in long lines or compact masses on the bars or flats which are exposed at low tide. The harbors of all the northern seacoast cities are visited in winter by numbers of these birds, constantly on the watch for any bits of refuse which may be thrown from the wharfs or vessels, or brought down by the tides or currents. Their long and powerful wings make the flight of even so heavy a bird a sight beautiful to watch, and the water looks deserted when the motion and color which the gulls furnish is absent. But it is not to the eye alone that the birds appeal.

The ceaseless activity of the gulls in pursuit of floating refuse and their inordinate appetite make them invaluable scavengers; without them, the refuse dumped into the water would return at each tide to pollute the shore. No idea can be formed of the value of the service performed by the gulls, till one sees the countless throngs which hover over the dumping grounds in the lower New York Bay, awaiting the arrival of the scows with the refuse from that city. As the buzzards and vultures are protected in all warm countries for their services in devouring carrion, so ought these scavengers of the northern seas to be guarded from persecution.

The adult Herring Gull in full plumage has pure white underparts, head and tail, but a gray mantle, as it is termed, is spread over the wings. Young birds, however, show many shades of brown, and 
attain the white only after a year or two. The small, elegantly built birds, known along the seacoast as Mackerel Gulls, are not strictly gulls, but terns. They may be known by their forked tails and by their black caps. It is they that hover screaming over the water, constantly darting down to strike at fish.

Gulls breed commonly along the coast of Maine and far northward. Great colonies occupy a small area, and a visit to their breeding places is a marvelous experience. At the approach of an intruder, the parents rise from their nests and circle about overhead, uttering hoarse cries, till the air is full of their wheeling forms. The downy young squat in the grass or bushes till the danger is past.

Both gulls and terns have long been persecuted for their soft white and gray plumage, which is coveted for the adornment of women's hats. As the destruction of the birds on the islands where they are breeding would soon destroy the whole race, efforts are being made by the lovers of birds to protect the birds on all the sandy points or rocky islands where they rear their young.

Gulls have wonderful powers of flight, and some species often follow ocean steamers for days, flying constantly about the vessel's stern, watching for bits of food which may be thrown overboard. When an object is spied the whole flock dart upon it, and it soon disappears among the crowd of struggling birds.

In the Eastern States gulls are always associated with the sea, but in the Mississippi valley certain species are found on the prairies, where they follow the plough to seize the upturned insects. 



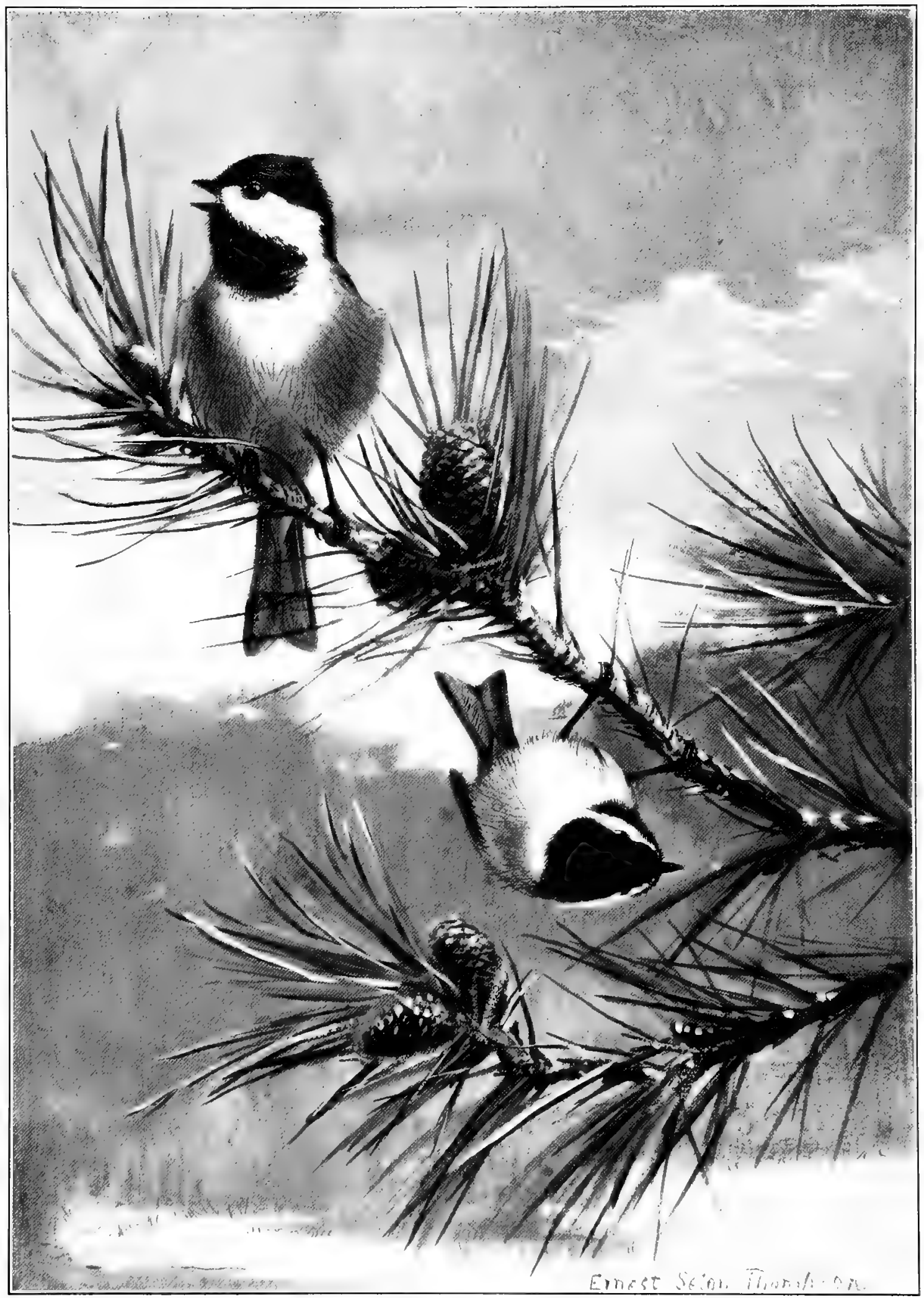

THE CHICKADEE 


\section{THE CHICKADEE}

Throughout the winter, bands of small birds visit the orchards and ornamental trees of every village and farm, gleaning dormant insects and their eggs from the twigs and boughs. The best known member and the leader, apparently, of the company is the Chickadee. There are generally about half a dozen of these birds together, possibly the parents and young of the preceding summer. The whole company are rarely in sight at any one time; some are in one tree, some are flying to the next, one perhaps is on the ground. There is a constant interchange of lisping call-notes, which break into excited gurgles, and the familiar tee, dee, dee, dee, when something excites their alarm or curiosity. It is not hard to disturb their composure; they come more easily than almost any other bird to the squeaking sound that bird students make to attract the attention of birds. One fluffy head after another pitches into the tree nearest the performer; then, by short stages, the boldest comes nearer to the strange sight and sound, often within arm's length. When their curiosity is appeased, they return to their examination of the twigs and branches, or, if startled by a sudden movement, they dive into the nearest cover.

Their positions when feeding on slender twigs are extremely graceful, and their agility surprising. When gathering sunflower seeds, of which they are extremely fond, they cling to the under surface of the drooping head and pick till they loosen the seed. Then they fly with it to a branch and hammer it open. A favorite winter food is the berry of the poison ivy. By tying a bone or 
a piece of suet to the branches of trees near the house, not only Chickadees but other birds as well will be attracted to the spot, and will become regular winter visitors. They are by no means confined, however, to villages and farms. Often as we push through the deep snows of the winter forests, the only sound will be the distant lisp of this hardy bird.

Besides the notes heard so commonly in winter, the Chickadee has a pensive and extremely gentle whistle, which it utters while sitting motionless, and oftener in spring than at other seasons, though it may be heard in every month of the year. It consists of two notes, an exact interval apart, and each accented. It is often mistaken, especially in early spring, for the song of the Phœbe, but it may be distinguished by its purity and sweetness. It is easily imitated by whistling, and the bird will often answer, or even fly toward the person whistling, and survey him with astonishment.

It is generally believed by people who see the bird only in winter that the Chickadees retire northward in spring; it is true that they then no longer frequent the yards and gardens, but in the woods and retired orchards many a pair have excavated some decaying birch or apple stump, and after lining it warmly with moss and feathers, provided amply for the continuance of their race; sometimes as many as nine eggs are laid. In winter, the birds spend the night in holes, not necessarily the same in which they were bred.

Several writers have mentioned instances of the extreme boldness of this bird; Mr. Chapman has had a Chickadee perch on his hand. One can easily imagine it, but we do not need such a mark of confidence to feel strong affection for this companionable and winter-loving bird. 




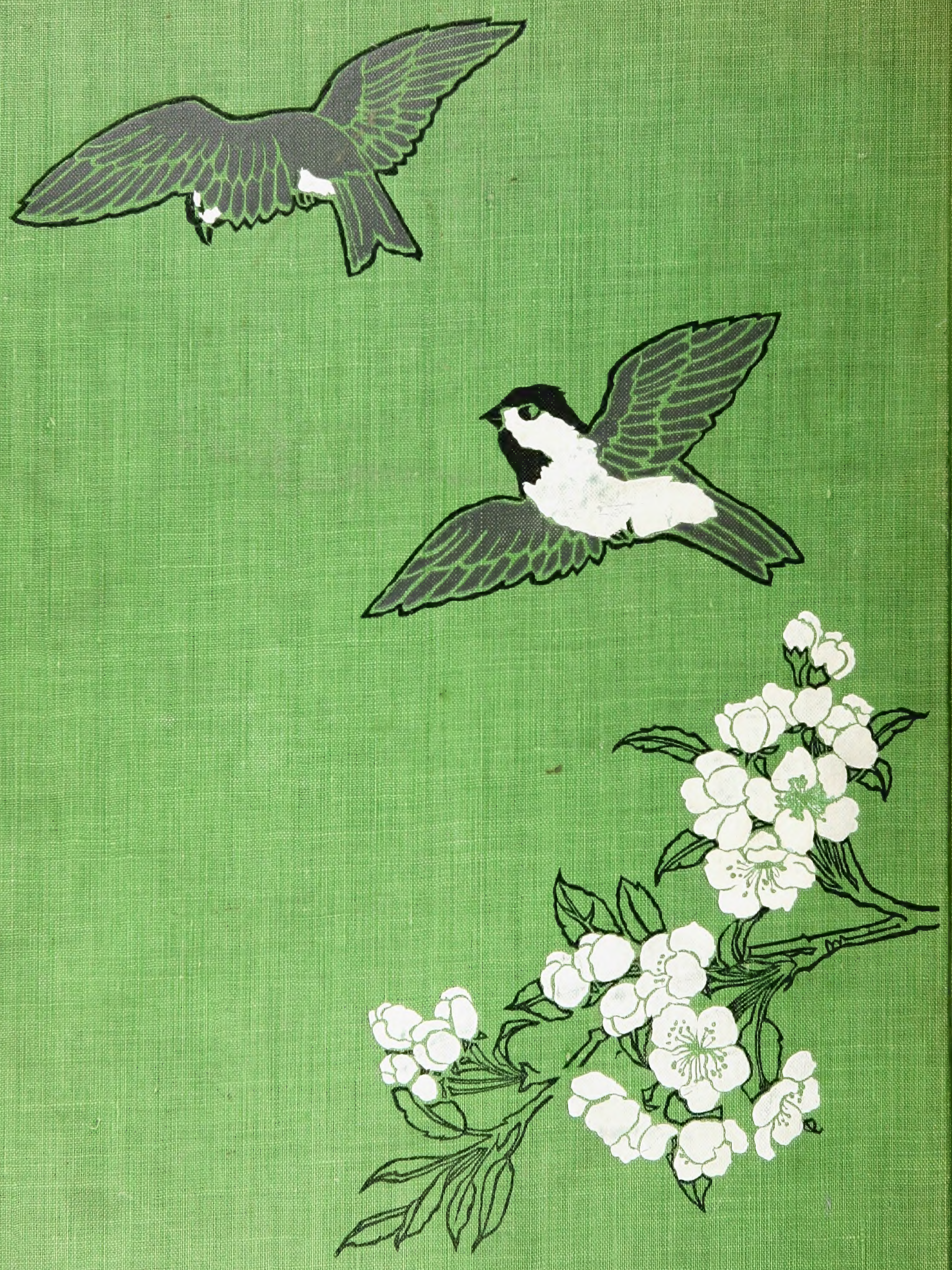